\title{
Ethnic Diversity and Economic Performance
}

\section{Citation}

Alesina, Alberto, and Eliana La Ferrara. 2005. Ethnic diversity and economic performance. Journal of Economic Literature 43(3): 762-800.

\section{Published Version}

http://dx.doi.org/10.1257/002205105774431243

\section{Permanent link}

http://nrs.harvard.edu/urn-3:HUL.InstRepos:4553005

\section{Terms of Use}

This article was downloaded from Harvard University's DASH repository, and is made available under the terms and conditions applicable to Other Posted Material, as set forth at http:// nrs.harvard.edu/urn-3:HUL.InstRepos:dash.current.terms-of-use\#LAA

\section{Share Your Story}

The Harvard community has made this article openly available.

Please share how this access benefits you. Submit a story.

Accessibility 

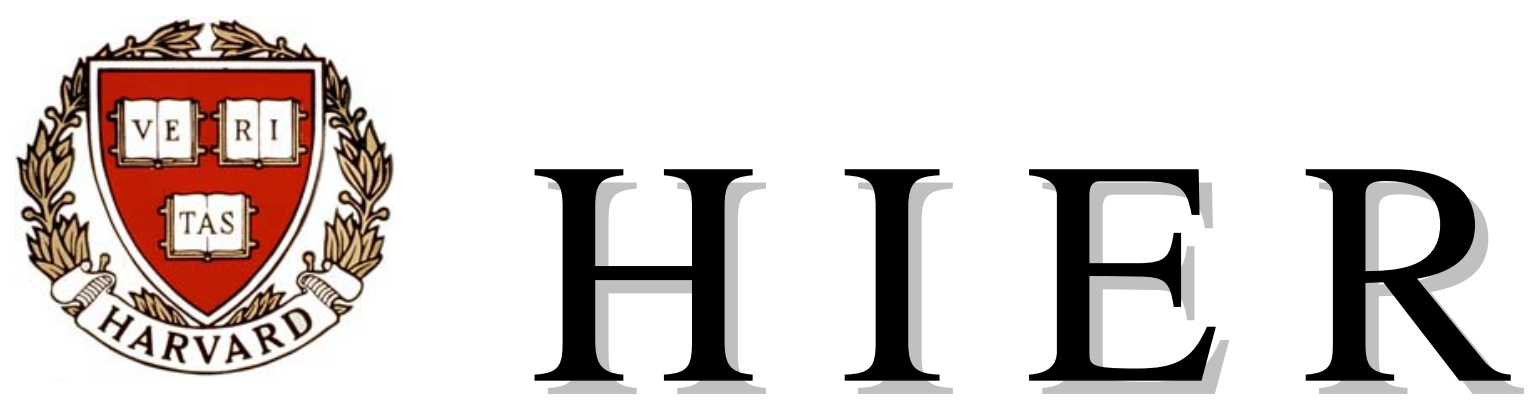

\section{Harvard Institute of Economic Research}

Discussion Paper Number 2028

Ethnic Diversity and

Economic Performance

by

Alberto Alesina
and

Eliana La Ferrara

December 2003

\section{Harvard University Cambridge, Massachusetts}

This paper can be downloaded without charge from:

http://post.economics.harvard.edu/hier/2003papers/2003list.html

The Social Science Research Network Electronic Paper Collection:

http://ssrn.com/abstract $=569881$ 


\title{
Ethnic Diversity and Economic Performance ${ }^{1}$
}

\author{
Alberto Alesina \\ Harvard University \\ NBER, CEPR
}

Eliana La Ferrara

Universita' Bocconi

IGIER

December 2003

${ }^{1}$ We thank David Laitin and two anonymous referees for very useful comments. Angelo Mele provided excellent research assistance. Alesina is grateful to the NSF for financial support through a grant to the NBER. 


\begin{abstract}
We survey and asses the literature on the positive and negative effects of ethnic diversity on economic policies and outcomes. Our focus is on countries, on cities in developed countries (the US) and on villages in developing countries. We also consider the endogenous formation of political jurisdictions and we highlight several open issues in need of further research.
\end{abstract}




\section{Introduction}

From the "tragedy of Africa" to social problems of American cities, the effects of racial conflict have risen to the center of attention not only of policymakers but also of academic researchers. ${ }^{1}$ While sociologists and political scientists have long been aware of the importance of these issues, only recently economists have begun paying more systematic attention to them.

The purpose of this paper is to discuss the question: is ethnic diversity "good" or "bad" from an economic point of view, and why? Its potential costs are fairly evident. Conflict of preferences, racism, prejudices often lead to policies which are suboptimal from the point of view of society as a whole, and to the oppression of minorities which may then explode in civil wars or at least in disruptive political instability. But an ethnic mix also brings about variety in abilities, experiences, cultures which may be productive and may lead to innovation and creativity. The United States are the quintessential example of these two faces of racial relations in a "melting pot". While much evidence points toward the problem of racial heterogeneity in US cities, the racially mixed and racially troubled New York City and Los Angeles are constant producers of innovation in the arts and business. In what follows we try to highlight the trade off between the benefits of "variety" and complexity and the costs of heterogeneity of preferences in a multi-ethnic society.

In order to bring more evidence to bear on this question we plan to examine jointly two strands of the literature that have proceeded in a parallel way: one on cross country comparisons, and one on local communities. The latter is itself split into two sub areas with little communication between the two, namely the public and urban economics literature on US cities on the one hand, and the development literature which focuses on groups and local communities on the other. Within both strands of the literature, one approach takes the size and number of jurisdictions (countries or localities) as given, and studies the effects of different degrees of ethnic fragmentation on quality of government, economic policies, growth, unrest, crime, civil wars etc. A second and less developed approach focuses on the fact that the number and size of political jurisdictions is itself determined by the ethnic composition of the population.

In the process of examining the existing literature we provide some new results and we highlight several open questions ranging from data and measurement problems, to unsolved empirical and theoretical puzzles, to policy implications. While we are of course perfectly aware that American cities are very different from African villages, we believe that highlighting similarities and differences in the findings may shed some light on the question at hand, for instance how different levels of development and different types of racial, linguistic or religious conflict play out in the political economy of various parts of the world. As always when reviewing a strand of the literature one has to put

\footnotetext{
${ }^{1}$ We use the terms "racial" and "ethnic" interchangeably when referring to fragmentation, although we are aware that the two concepts differ and we shall highlight the differences when in order.
} 
boundaries. We limit ourselves to "direct" economic effects of diversity; we leave aside indirect effects that may go trough civil wars. crime, revolutions etc.

We proceed in the following way. In section 2 we discuss the theoretical underpinnings of the relationship between ethnic diversity and economic performance. We also sketch a simple model, which has no pretence of being innovative but illustrates clearly the pros and cons of ethnic fragmentation and sets the stage for the discussion of the literature (mostly empirical) that follows. Section 3 discusses the effects of ethnic and racial fragmentation in various types of communities holding the number and size of communities as exogenous. We examine evidence collected on three types of communities: social groups, localities and nations. Section 4 discusses the question of endogenous formation of groups, localities and nations. Section 5 concludes by discussing several open questions in this area of research. The last section attempts to draw some tentative conclusions and policy implications.

\section{Theories on diversity}

The goal of this section is to briefly highlight some economic motivations underlying the relationship between ethnic diversity and economic performance. Since no comprehensive treatment of this is available, we start by gathering different contributions that can give a more or less coherent picture of the microfoundations for this relationship. Having established such microfoundations, we then move to analyze the impact of diversity on policies and productivity through a simple reduced-form model.

\subsection{Some "microfoundations"}

The most basic way in which ethnic diversity can affect economic choices is by directly entering individual preferences. Early work on social identity theory has established that patterns of intergroup behavior can be understood considering that individuals may attribute positive utility to the well being of members of their own group, and negative utility to that of members of other groups (see e.g., Tajfel et al. (1971)). A recent formalization of this concept is the analysis of group participation by Alesina and La Ferrara (2000), where the population is heterogeneous and individual utility from joining a group depends positively on the share of group members of one's own type and negatively on the share of different types.

A second way in which diversity can affect economic outcomes is by influencing the strategies that individuals play. Even when individuals have no taste for or against homogeneity, it may be optimal from an efficiency point of view to transact preferentially with members of one's own type if there are market imperfections. For example, Greif (1993) argues that traders in Medieval times formed coalitions along ethnic lines in order to monitor agents by exchanging information on their opportunistic behavior. Ethnic 
affiliation helped sustain a reputation mechanism in the presence of asymmetric information. But strategies can be conditional on one's ethnic identity also in the presence of perfect information. La Ferrara (2003a) shows that when contracts cannot be legally enforced (and therefore have to be "self-enforcing"), membership in ethnic groups allows to enlarge the set of cooperative strategies that can be supported. The reason is that both punishment and reciprocity can be directed not only to the individual but to other members of his/her group. A similar reasoning is proposed by Fearon and Laitin (1996) to explain inter-ethnic cooperation.

Finally, ethnic diversity may enter the production function. Alesina Spolaore and Wacziarg (2000) employ a Dixit Stiglitz production structure where more variety of "intermediate inputs," that can be interpreted as more variety of individual skills, increases total output. This model, however, does not identify a trade off in the production function since more heterogeneity is always better than less. The costs of heterogeneity are outside the production function. Lazear (1999 a, b) also discusses how different skills in a production unit may increase overall productivity. He identifies a trade off between the productive benefits of diversity and the possible costs that may arise due to difficult communication between people with different languages, culture etc. There is an optimal degree of heterogeneity that is identified by the optimal point of this trade off given also the nature of the production unit and its technology. An empirical paper by O' Reilly Williams and Barsade (1997) brings supportive evidence on these hypothesis. They analyze 32 project teams and find that more diversity lead to more conflict and less communication, but controlling for the latter it also leads to higher productivity. Pratt (2000) raises related points in the context of team theory. In teams where jobs are complementary homogeneity has positive effects and the other way around. Ottaviano and Peri (2003) also investigate the pros and cons of diversity in production. Diversity and related amenities affect the value of land (rents) which enters the production function.

\subsection{Costs and benefits of diversity: a simple model}

\subsubsection{Private goods, public goods and diversity}

We provide here an elementary model that helps to clarify the pros and cons of ethnic diversity and offers a useful perspective for a review of the empirical literature. Consider a community, say a country, with $K$ different types of individuals, for a total population of $N$ individuals. For simplicity, every group has the same size $s=N / K$. Output produced in the country is given by:

$$
Y=N f(x ; K)
$$

where $x$ is the fixed amount of input, say labor, equal for every person and type. We assume that $f_{x}>0, f_{x x}<0$, where subscripts denote partial derivatives. If variety in 
production is "good" then we have $f_{K}>0, f_{K K}<0$. This is the simplest possible way of capturing a benefit from variety in production, since per capita income is increasing in the number of different types in the population. We also assume complementarity, i.e. $f_{x K}>0 .^{2}$

Output can be either consumed privately or used to produce a public good, $g$. Individual utility is separable in the private and public good and is given by:

$$
U^{i}=u\left(c_{i}\right)+v(g, K)
$$

where $u_{c}>0, u_{c c}<0, v_{g}>0, v_{g g}<0$. We also assume $v_{K}<0$, and $v_{g K}<0$, implying that the enjoyment of the public good is decreasing with the number of types in the population. These preferences can be rationalized in two ways. One is that sharing a public good implies contacts between people, and contacts across types produce negative utility, as in Alesina and La Ferrara (2000). A different rationalization follows Alesina and Spolaore (1997). They distinguish between different kinds of public goods in a context where the public good chosen is the one preferred by the median voter. The larger the number of types in the population the larger the average distance between each type an the median one that chooses the public good. ${ }^{3}$

The budget constraint implies:

$$
g=t N f(x, K)
$$

where $t$ is the income tax rate. Suppose that a benevolent government can choose the tax rate, for given number of types. The problem is:

$$
\begin{array}{ll}
\max & N[u(c)+v(g, K)] \\
\text { s.t. } & N c+g=N f(x, K) \\
& g=t N f(x, K)
\end{array}
$$

The first order condition that defines an interior solution for this problem is:

$$
N v_{g}(\cdot)=u_{c}(\cdot)
$$

This equation implies that the marginal benefit of taxation in terms of production of public good (LHS) has to be equal to the marginal cost of taxation in terms of reduction of private consumption (RHS). Distortionary taxes on, say, the labor supply would not change the basic message. Standard applications of the implicit function theorem and of the envelope theorem lead to the following result:

\footnotetext{
${ }^{2}$ This can be considered a reduced form simplification of a production function with a variety of inputs a la Dixit-Stiglitz as used by Alesina, Spolaore and Wacziarg (2000).

${ }^{3}$ In Alesina and Spolaore (1997) there are multiple kinds of public goods to be supplied with fix quantities. More generally, both the type and the quantity of public goods could change.
} 


$$
\text { sign }\{d t / d K\}=\operatorname{sign}\left\{t N^{2} v_{g g} f_{K}+N v_{g K}-(1-t) u_{c c} f_{K}\right\} .
$$

Note that we are holding $N$ constant to isolate the effects of more fragmentation without changing total population size. While the sign of (5) is generally uncertain, $d t / d K<0$ as long as $v_{g K}$ is large enough in absolute value. The intuition for this condition is clear: as long as the marginal benefit of public consumption goes down substantially with an increase in ethnic fragmentation, then a larger $K$ means that the social planner will choose a smaller size of the public good in favor of more private good. The only force working against this effect is the decreasing marginal utility of the private good. In what follows we refer to the case where $d t / d K<0$ as our "benchmark" case. This benchmark implies that, as a country becomes more ethnically fragmented, it may become more productive but it will choose to have a smaller size of government (remember that $t=g / Y$, thus $t$ represents the size of government). More generally private consumption will increase but public consumption will decrease. This is an empirical implication which we shall test below. ${ }^{4}$

Another application of the implicit function theorem leads to the following result:

$$
\operatorname{sign}\{d t / d x\}=\operatorname{sign}\left\{t N^{2} v_{g g}-(1-t) u_{c c}\right\} \text {. }
$$

Note that if $d t / d x<0$, then, a fortiori, $d t / d K<0$. However one could have $d t / d x>0$ and $d t / d K<0$, i.e., it is perfectly possible that the size of government is increasing with the level of individual productivity $x$, and thus in GDP, but decreasing in fragmentation.

We next allow the social planner to choose not only the level of taxation but also the optimal number of types, $K$, again holding the size of the country constant. The first order condition for an interior solution with respect to $K$ is:

$$
u_{c}(\cdot)(1-t) f_{K}+v_{g}(\cdot) t N f_{K}=-v_{K}(\cdot)
$$

and the second order conditions are satisfied. Condition (7) equals the marginal benefits of letting in an additional group in terms of increased productivity and tax revenues (LHS) to the marginal costs of having one more group to share the public good with (RHS). ${ }^{5}$

An interesting comparative statics exercise regards the effect of an increase in $x$ (individual level of input/productivity) on the optimal number of groups. Straightforward algebraic computations establish, under very general conditions, the following: 6

\footnotetext{
${ }^{4}$ Note of course that if $f_{k}<0$, then income per capita would go down as fragmentation increases and the allocation of this lower total output between private and public consumption would depend on the marginal benefits of the two.

${ }^{5}$ Note that if there were no benefits in production from variety $\left(f_{K} \leq 0\right)$, then the solution would be at a corner with the minimum number of groups, possibly 1, that is, a fully homogeneous society. The first order condition for the choice of $t$ is of course unchanged.

${ }^{6}$ Intuitively, these conditions require that the indirect effects of a a change in $t$ caused by a change in $K$ do not override the direct effect of a change in $x$ on $K$. Details are provided in the appendix.
} 
Remark 1 If $f_{x K}$ is positive and sufficiently large, then $d K / d x>0$.

A higher level of per capita input raises the benefits of variety and increases the optimal number of groups if the cross partial $f_{x K}$ is large enough. In this case, as the level of individual output increases the productivity gains from variety go up as well, so the benefit from more ethnic fragmentation are increasing with the level of per capita output. This is an empirically plausible implication: the benefits of skill differentiation are likely to be more relevant in more advanced and complex societies.

\subsubsection{On the number of jurisdictions}

The same theoretical framework can be extended to analyze the optimal number of jurisdictions, along the lines of Alesina and Spolaore (1997, 2003). We can think of the optimal size of a jurisdiction (say a country) to emerge from the a trade off: the benefit form variety and the costs of heterogeneity. In the language of our model above we could think of a social planner choosing the size $s$ with the goal of maximizing total welfare. The trade off between benefits and costs of heterogeneity would deliver an optimal size. Needless to say the larger the effect of variety in production and the lower the utility costs of heterogeneity the larger the size of the jurisdiction chosen by the social planner. ${ }^{7}$

Given our analysis above, should we then expect larger countries to be more productive because they have more variety? The answer depends on the structure of international trade. With sever trade restrictions, country size would be very important for productivity; on the other hand with free trade countries can be small, enjoy the benefit of homogeneity as far as public goods provision is concerned but enjoy diversity in production ( and consumption) by means of international trade. ${ }^{8}$ Note that some ethnic fractionalization in country may favor trade as well. For instance a certain ethnic minority in country A can be a "link" with a country B where that ethnic group is a majority, therefore facilitating trade between $\mathrm{A}$ and $\mathrm{B}$. The extent in which ethnic and cultural relation facilitate trade and more generally economic integration is well established See for instance Huntington (1994) for an informal discussion and Casella and Rauch $(2001,2003)$ for models and empirical evidence. The same kind of trade off between economies of scale of being large and the cost of heterogeneity public policy decisions, is applied to discuss the formation of local governments within a country with specific reference to the US by Alesina Baqir and Hoxby (2004). They show how an

\footnotetext{
${ }^{7}$ An important question is under which condition the optimal solution would or would not be reproduced by "the market" without a social planner, a question explored in a variety of setting by Alesina and Spolaore (2003). In general the answer is no and the "equilibrium size of jurisdictions" would vary as a function of various aspect of political institutions and available rules to change borders, a set of issue that we do not purse here.

${ }^{8}$ One implication of this is that he effects of the size of countries on economic success is mediated by the extent of freedom of trade, a result empirically supported by Ades and Glaeser (1995), Alesina Spolaore and Wacziarg (2000) and Alcala and Ciccone ( 2004) amongst others.
} 
increase in heterogeneity in a county in the US leads to a formation of a larger number of smaller localities (cities and school districts).

\subsubsection{Summing up the implications of the theory}

The potential benefits of heterogeneity come from variety in production. The costs come from the inability to agree on common public goods and public policies. One testable implication is that more heterogenous societies may exhibit higher productivity in private goods production but lower taxation and lower production of public goods. The benefits in production from variety in skills are more likely to be relevant for more advanced societies. While in poor economies ethnic diversity may not be beneficial form the point of view of productivity, it may be so in rich ones. The more unwilling to share public good or resources are the different groups, the smaller the size of jurisdictions. The larger the benefits in production from variety, the larger the size. If variety in production can be achieved without sharing public goods, different groups will want to create smaller jurisdictions to take advantage of homogeneity in the enjoyment of the public good broadly defined.

\subsubsection{What is not in the model}

Amongst the many relevant aspects of the problem left out from the model several are worth mentioning. One has to do with the interaction between institutions and ethnic fractionalization. Certain types of institutions may be more conducive to ethnic harmony than others. Collier $(2000,2001)$ for instance argues that ethnic fragmentation is less disruptive in democracies. The idea is that in this type of political system minorities feel represented and less oppressed than in dictatorships. Alesina and Spolaore (2003) argue that rent extracting dictators would want to have large countries and may devote some resources to repress minorities. We examine these points empirically below.

Note however that the type of government chosen may not be exogenous to the nature of the ethnic conflict, a point made by Aghion, Alesina and Trebbi (2002). They argue that in a racially fragmented society if a group manages to hold up the political process it may impose a less democratic system that favors the group itself. On the other hand id the constitutional process is truly representative of all groups then indeed more fragmentation may lead to the choice of political structure which are more representative.

The second missing aspect in the above model is that while pure public goods may be lower in more fragmented communities, the amount of publicly provided "private" goods - especially those that can be targeted to specific groups- may be larger. It is then possible that an association between fragmentation and ethnically based patronage or even corruption is created.

Third, in the model an increase in ethnic animosity would simply lead to smaller jurisdictions. In practice this process may be peaceful or not, leading to violent civil 
wars. This is an important topic that we do not investigate directly here; we refer the reader to Fearon and Laitin (2000), Fearon (2002) and the references cited therein.

\section{The effects of ethnic fragmentation on productiv- ity and income levels}

In this section we review the main contributions that have linked ethnic fragmentation to economic outcomes, going from the more aggregate level (country level fragmentation and performance) to the more micro level, i.e. local jurisdictions (cities, districts) down to the level of small groups (schools, associations, cooperatives).

\subsection{Countries}

Economists have started to pay substantial attention to the effects of racial fragmentation across countries at least since a paper by Easterly and Levine (1997). These authors argued that, ceteris paribus, more racially fragmented countries grow less and that this factor is a major determinant of Africa's poor economic performance. ${ }^{9}$ Several subsequent papers confirmed these results in the context of cross country growth regressions. In their excellent overview of Africa's problem Collier and Gunning (1999) also place much emphasis on ethno linguistic fractionalization (coupled with low political rights) as a major explanation for the lack of social capital, productive public goods and other growth enhancing policies.

Easterly and Levine's paper, as much of the literature that followed, used as a measure of fragmentation the probability that two randomly drawn individuals from the unit of observation (say, country) belong to two different groups. Their ethno-linguistic fractionalization (ELF) measure is an Herfindahl index defined as follows

$$
E L F=1-\sum_{i} s_{i}^{2}
$$

where $s_{i}$ is the share of group $i$ over the total of the population. Using data from a Soviet source, the Atlas Novi Mira, Easterly and Levine conclude that a large portion of "Africa's growth tragedy" can indeed be attributed to the effect of racial fragmentation. This conclusion has spurred a vivid debate and has generated a significant amount of research on the relationship between ethnic diversity and economic growth. Apart from issues of measurement (to which we return below), the robustness of Easterly and Levine's results has been called into question by Arcand et al. (2000) due to problems of data missingness. ${ }^{10}$ Despite the criticisms, subsequent estimates have taken Easterly

\footnotetext{
${ }^{9}$ An early unpublished paper by Canning and Fay (1993) raised a similar point.

${ }^{10}$ Arcand et al. (2000) note that African countries constitute only 27 of the 172 observations in Easterly and Levine's main regression, and highlight the potential sample selection bias generated by
} 
and Levine's results as a benchmark.

Using the updated dataset of Alesina et al. (2003), we now test whether the negative correlation between ethnic fragmentation and growth holds irrespective of the level of economic development or, as our model suggested, is mitigated when the benefits of heterogeneity for productivity are taken into account. ${ }^{11}$

\section{[Insert Table 1]}

Table 1 shows some standard growth regressions adopting the baseline specification of Alesina et al. (2003). The dependent variable is the growth rate of GDP per capita from 1960 to 2000 and we use a SUR method in four 10-years periods. The first two columns use the more comprehensive index of fractionalization (which we label $E L F$ ), while columns 3 and 4 use the one based solely on language. Columns 1 and 3 show a baseline regression with very few controls: regional dummies, initial income and schooling. Columns 2 and 4 include additional controls, such as measures of political stability and quality of policy. One may argue (and in fact we explore this point below) that the effect of fractionalization on growth may go through exactly these variables; therefore by controlling for these variables one may underestimate the effects of fractionalization on growth. Overall table 1 shows considerable support for the negative effects of fractionalization on growth. ${ }^{12}$ In terms of magnitude, the estimates in column 1 suggest that ceteris paribus going from perfect homogeneity to maximum heterogeneity (i.e., increasing ELF from 0 to 1) would reduce a country's growth rate by 2 percentage points. This is quite a sizeable effect. All the other controls have signs consistent with the vast literature on growth. ${ }^{13}$

\section{[Insert Table 2]}

An important question is whether or not these negative effects from ethnic fractionalization on growth depend on the level of income or other features of society. In the model of section 2 we showed that under reasonable conditions on technology, fractionalization may have positive (or less negative) effects on output at higher level of

the fact that the data is missing precisely for those countries (in Africa) that have experienced slower growth.

${ }^{11}$ Measurement and data issues are discussed below in section 6.5. A brief description of the data is contained in the Appendix.

${ }^{12}$ These results are very similar to those reported by Alesina et al. (2003). The only difference is that they use both a linear and a quadratic term for initial per capita income. We use only the linear one because below we explore interactions of the initial level of income with other variables and we wanted to keep a simpler specification. In any case results with a quadratic term for initial income are very similar for our variables of interest.

${ }^{13}$ For instance there is evidence of conditional convergence (since the coefficients on in initial GDP per capita are negative), schooling has positive effects on growth as well as infrastructure measured as telephone per workers, political instability measured by assassination has negative effect on growth etc. The two regional dummies for Sub Saharan Africa and Latin America have negative coefficients. 
development. Table 2 adds to all the regressions of Table 1 an interaction term between fractionalization and GDP per capita. In all four regressions the interaction of initial GDP per capita and fractionalization has the expected (positive) sign, suggesting that indeed fractionalization has more negative effects at lower levels of income. In two out of four regressions, this effect is strongly statistically significant.

\section{[Insert Table 3]}

Collier (2000) argues that fractionalization has negative effects on growth and productivity only in non democratic regimes, while democracies manage to cope better with ethnic diversity. This is an important result worth exploring further. Obviously, per capita GDP and indices of democracy are strongly positively correlated: richer countries tend to be more democratic. Apart from the reasons why this is the case, form a statistical point of view this high correlation implies that it is quite difficult to disentangle the effects of democracy from the effects of the level of income on any dependent variable that might be affected by either one or both. Table 3 considers the effects of the interaction of ethnic and language fractionalization with the Gastil index of democracy. Note the index is a decreasing measure of democracy so the expected sign on the interaction with the fractionalization is negative. The estimates in this table are consistent with Collier's findings that fractionalization has less negative effects in democracies.

\section{[Insert Table 4]}

Table 4 uses the two basic specifications to try and disentangle the effects of income and democracy. Since we are adding several variables with interactions we use the simpler specification. Overall the effect of income seems more robust and more precisely estimated than the effect of democracy. However these results have to be taken cautiously given the high correlation between democracy and GDP per capita. The punch line is that rich democracies are more capable of "handling" productively ethnic diversity. Note, however, that as argued above the variable "democracy" may be endogenous to ethnic diversity. It may be the case that racially fragmented societies that choose democratic institutions are also those in which ethnic cleavages are less deep and/or the power distribution of groups is such that none can impose a non democratic rule.

Related to the issue of how democracy interacts with ethnic conflict and with the level of development is the role played by institutions in general. Easterly (2001) constructs an index of institutional quality aggregating Knack and Keefer's (1995) data on contract repudiation, expropriation, rule of law and bureaucratic quality. He finds that the negative effect of ethnic diversity is significantly mitigated by the presence of "good" institutions, and the marginal effect of ethnic diversity at the maximum level of institutional development is actually zero. Again, the institutional variables used as explanatory factors are likely not exogenous, and more work needs to be done to assess the marginal impact of institutional arrangements. Nonetheless, it seems important to 
take into account that, whatever the mechanisms relating ethnic diversity to economic growth, channelling diversity towards productive uses may require a particular set of "rules of the game".

\subsection{American localities: counties and cities}

American localities are an ideal setting to study the effects of ethnic fragmentation because we have many observations and excellent data, compared, say, to cross country data. Glaeser, Scheinkman and Shleifer (1995) have examined the growth of US cities using a similar structure to cross country growth regressions. They argue that the most appropriate measure of growth to use in this case is population growth. They note that income growth is a natural measure for cross country growth regressions because labor is relatively immobile across countries. Instead within the US the high mobility of individuals suggests that population growth is the correct measure to use to capture areas and cities that are becoming increasingly more attractive economically and as a place to live in. As Blanchard and Katz (1992) have noted, migration within the US responds strongly and relatively quickly to income opportunities.

Glaeser, Scheinkman and Shleifer (1995) do not find any effect of racial fragmentation on the growth of cities in the sample 1960 to 1990. Their only finding concerning racial composition is that "in cities with large nonwhite communities segregation is positively correlated with population growth". This result suggests that growth is higher when racial interaction is lower because of segregation. A suggestive interpretation of this result that goes back to our model may be that racial fractionalization with segregation may allow for diversity in production and lower interaction in public good consumption and social activity. Rappaport (1998) also studies population growth in cities and counties in the US. He controls for many more determinants of counties' characteristics and amenities and he finds that more racially fragmented counties grow less in terms of population.

\section{[Insert Tables 5, 6]}

In Table 5 and 6 we present some results on population growth in counties that are in line with our cross country results. For the reason discussed above we follow the literature in using population growth as our dependent variable. Table 5 reproduces for counties instead of cities and for a different sample (1970-2000) the basic specification of Glaeser, Scheinkman and Shleifer (1995). We do not find any effect of fractionalization on population growth. In Table 6 we add an interaction of initial per capita income level and fractionalization and we experiment with different samples, noting that we do not have data on income per capita before 1970. Broadly speaking, the results are consistent with the cross country results: we find that fractionalization has a negative effect of population growth in initially poor counties and a less negative (or even positive) effect for initially richer counties. This result significantly corroborates the cross country 
evidence in a setting where institutional and political differences should be definitely lower than across countries.

Two recent papers have looked directly at the productivity enhancing effects of diversity in American cities. Ottaviano and Peri (2003) use data on rents and wages in US cities and find that US born individuals living in more "culturally diverse" cities (i.e., cities with a larger share of foreign born people) earn higher wages and pay higher rents than those living in more homogeneous cities. In other words, diversity seems to have positive "amenity effects" on production and consumption. Their findings are robust to instrumenting the share of foreign born people with the distance from the closest "port of entry" into the US. Along similar lines Florida (2002a,b) argues that amenities and diversity in US cities attracts human capital. He constructs imaginative indices of heterogeneity of a place that are not directly related to ethnicity but involve proportions of gay households, diversity of night life, etc. and finds that places that score higher in these indices have also higher human capital. The direction of causality is however unclear. Further work, possibly using firm and plant level data, would be useful in this area.

\subsection{Firms and groups in developing countries}

A particularly relevant setting in which to study the productivity effects of ethnic diversity is that of developing economies. The reason is that a large share of economic transactions occur outside the boundaries of the formal sector, and need to be supported by enforcement schemes similar to those described in section 2.1. Although direct empirical evidence is seldom available, a number of recent studies on developing countries allow to draw preliminary inference on the impact of diversity on productivity and economic performance at the micro level.

Manufacturing firms in Africa have been studied by several authors. Bigsten et al. (2000) use a dataset on Kenyan firms in the food, wood, textile and metal industries, and examine what factors account for the choice of going formal, and for the degree of economic efficiency. They find that kinship and community ties among entrepreneurs of Asian origin reduce the barriers to entry in the formal sector, so that even after accounting for differences in education, "African" firms are much more likely to be informal at start-up. ${ }^{14}$ In addition to the advantage that the "formal status" gives to Asian-managed firms (e.g., in terms of access to formal credit), the latter are shown to be more capital intensive and more productive. ${ }^{15}$

Fafchamps (2000) focuses on the relationship between ethnicity and access to credit

\footnotetext{
${ }^{14}$ The distinction between the Asian and the African business community in Kenya goes back to the colonial period, when the British organization rested upon a three-tier society in which traders and businessmen of Indian origin occupied an intermediate position.

${ }^{15}$ Further evidence on the relationship between ethnic networks and access to credit in the Kenyan manufacturing sector is provided by Biggs et al. (2002).
} 
for manufacturing firms in Kenya and Zimbabwe and finds that, after controlling for observable firm characteristics (e.g., size) African firms are not discriminated against in the allocation of bank overdraft and formal loans. The way in which ethnicity seems to make a difference is by offering network relationships that improve access to supplier credit. This in turn affects productivity and allows firms to remain in the market in the presence of negative shocks, as a common way to absorb cash flow variations is to delay payments to suppliers. The relationship between trade credit and productivity is further explored by Fisman (1999, 2003), who shows that entrepreneurs of Asian and European origin are more likely to obtain supplier credit, and that firms that do not have access to supplier credit have a higher probability of facing inventory shortages and have lower rates of capacity utilization. Despite their focus on employer-level ethnicity as opposed to ethnic fragmentation, the above studies potentially bear interesting implications for the relationship between ethnic diversity at the community level and firm performance. In fact, for a given level of credit supply, the greater the number of ethnic groups in the business community, the lower the chances that supplier credit is allocated efficiently if the criterion is purely ethnic affiliation, which can ultimately harm economic productivity. ${ }^{16}$

An explicit focus on ethnic heterogeneity and economic performance is in the study by La Ferrara (2002b). She uses an original dataset on production cooperatives in the informal settlements of Nairobi, and has information on all members of the surveyed groups, which allows to construct exact measures of group composition in terms of income, education, age and ethnicity. She finds that ethnicity matters for gaining access to group resources, especially in the form of cheap loans: members who share the same ethnicity as the chairperson are 20 to 25 percentage points more likely to borrow from the group or from other members. Ethnic heterogeneity also seems to influence the organization of production: members of more ethnically heterogeneous groups are less likely to specialize in different tasks and more likely to all do the same job. Also, ethnically fragmented groups more often adopt remuneration schemes in which every worker gets the same fixed amount, rather than being paid on the basis of the amount of work put in. These choices on division of labor and wage structure may be due to the relative difficulty of reaching consensus on "unequal" task allocations and remuneration schemes in ethnically heterogeneous groups. In this case, the consequences of ethnic diversity on differential access to inputs get reinforced by its impact on within-firm organization of production.

A recent application to lending groups is provided by Karlan (2003). He uses data on members of a Peruvian micro finance organization, and exploits the random selection of people into groups to estimate the effect of group composition on repayment performance. He finds that members of more "homogeneous" groups, both in terms of geographical proximity and of cultural affiliation, are more likely to save and to repay their

\footnotetext{
${ }^{16}$ This obviously depends on the way in which network structure endogenously responds to the ethnic composition of the community, a point we address in section 5.3.
} 
loans. Interestingly, "cultural" homogeneity is measured through a score attributed by enumerators to each respondent on the basis of his/her language, dress and hair style. These findings suggest that monitoring and enforcement within groups are easier the greater the social affinity among their members, as argued in section 2.1.

Finally, although very limited evidence exists on the subject, ethnic diversity can have an impact also on agricultural productivity in developing countries. A recent study by Macours (2003) suggests that informal enforcement of property rights in the land market creates incentives for rental transactions to remain within ethnic groups. In turn, in a highly fragmented environment, the exclusion of minority groups leads to ethnic conflict, further weakening property rights and reinforcing segmentation.

\section{The effects of ethnic fragmentation on public poli- cies}

\subsection{Countries}

An important prediction of the model sketched in section 2 is that the propensity to supply true public goods should be lower in more ethnically fragmented societies. The empirical literature has focused more on the "quality" than the "quantity" of public goods partly because of data availability. In order to carefully test the implication of the model on the quantity of public goods provision one would need aggregate measures of the various components of the government budget for a relatively large group of countries. These data are notoriously of poor quality and not disaggregated enough. Therefore results in this area have to be taken cautiously.

La Porta et al. (1999) and Alesina et al. (2003), amongst others, show that ethnic fragmentation is negatively correlated with measures of infrastructure quality, illiteracy and school attainment and positively correlated with infant mortality. These correlations are very strong in regressions without income per capita (that may be endogenous to ethnic fragmentation). They lose some of their significance in regressions where on the right hand side one controls for GDP per capita. Another variable that is correlated with racial fragmentation is latitude and this high correlation makes it sometimes difficult to disentangle the two effects separately. Often both variables used together are insignificant while they are significant if used separately. It should be made clear, more generally, that these authors do not argue that ethnic fragmentation is the only cause of "poor quality of government". For instance La Porta et al. (1999) argue that legal origins are at least as important.

An interesting related question regards the size of transfers rather than public goods. For a large sample of countries, Alesina, Glaeser and Sacerdote (2001) show an inverse relationship between the size of government social spending and transfers relative to GDP on one hand, and ethnic fractionalization on the other. One explanation is that 
altruism does not travel well across ethnic lines. Relating this point to the model above, one can view redistributive policies as a "public good" in a society that values equality as a public benefit. On this point a comparison between US and Europe seems especially suggestive. In the US welfare spending and redistributive policies are much smaller than in Europe, consistently with the fact that the US are much more racially and ethnically diverse than most countries in Continental Europe. ${ }^{17}$

\subsection{Cities}

A very large literature in political science and sociology examines the role of race in the history and dynamics of American cities. We cannot even begin to review this literature. For a recent contribution in this vein see Burns (1998) and the references cited therein. Several papers in economics have argued that public good provision is lower and/or less efficient in more racially fragmented American cities. These results are consistent with those obtained in cross country samples and in many ways follow similar procedures that involve cross cities (rather than cross country) regressions. Alesina, Baqir and Easterly $(1999,2000)$ show that in more fragmented cities the provision of "productive" public goods is lower. In the first paper they examine the composition of the budget of American cities, metropolitan areas and counties. They find that in more fragmented communities public budgets are tilled away from "productive" public goods. In the second paper they find that public employment as a share of the population is higher in more racially fragmented cites, a result consistent with a use of public jobs with ethnically or racially motivated patronage. Interestingly they find that racial divisions have stronger effects than ethnic ones, a result consistent with evidence discussed in the next section on the endogenous formation of localities in the US.

A particularly relevant type of local public good is public education. Poterba (1997) finds that in US states government per child spending on K-12 education decreases with the fraction of the population aged 65 and above, and that this effect is strengthened when the difference between the fraction of nonwhite population aged 5-17 and the fraction nonwhite aged $65+$ is included among the controls. This suggests an interplay of demographic and racial composition effects, as if older citizens were less inclined to spend on public goods that benefit younger generations when these generations belong disproportionately to a different race. Using historical data on US states, Goldin and Katz (1999) find a similar role for heterogeneity, be it ethnic, racial, religious or economic. Vigdor (2004) finds that the greater a community's racial heterogeneity, the lower its rate of response to the 2000 Census form. Response is interpreted as a local public good in that the amount of federal funds allocated to the community depend on its response rate.

One of the reasons why public policies in racially fragmented communities are worse

\footnotetext{
${ }^{17}$ See Alesina and Glaeser (2004) for data and analysis and Lee and Roemer (2003) for an analysis of the same problem.
} 
is that social capital is lower. Two key aspects of social capital are participation in social activities and social groups and trust. ${ }^{18}$ Using data from the General Social Survey (GSS), Alesina and La Ferrara (2000) provide evidence that in American cities individuals of different races are less willing to participate in social activities in racially mixed communities. There are two non mutually exclusive explanations. One is that members of different racially identified groups have different preferences on the what group should do or how it should be run, and the other is that there is a cost in sharing a group with different races simply because of aversion to racial mixing. Alesina and La Ferrara (2002) show that in American cities individuals living in more racially fragmented communities have a lower propensity to trust other people, while they do not exhibit lower levels of trust towards institutions. Similar results were later obtained by Putnam (2002) and Costa and Khan (2003b). Interestingly, all these authors also show that income inequality reduces participation and social capital but the effect of racial conflict seems stronger. Experimental evidence on trust and participation included in Glaeser et al. (1999) is also consistent with these results: even in experimental settings and amongst a relatively homogeneous group of individuals (in terms of education), trust does not travel well across racial lines.

Alesina and La Ferrara (2002) also show how redistributive policies are deeply affected by racial politics. In more racially fragmented communities people are less willing to redistribute income because the white majority feels that redistributive flows would favor a racial minority. Survey evidence suggests that those respondents who express attitudes less favorable to racial integration are also more averse to government intervention on redistributive matters.

\subsection{Communities in developing countries}

A well known line of research in the public economics literature has looked at the impact of heterogeneity on public good provision by groups or small communities, focusing on the relationship between inequality in the shares of the benefits from the commonly provided good that accrue to different types and their incentives to contribute. ${ }^{19}$

In Olson's (1965) seminal contribution, the extent to which individuals benefit from the common good is positively related to their initial endowments, and the effect of increased inequality on collective action is positive. His argument is that, for given group size, richer members have more incentives to contribute resources and/or to monitor others, so that higher inequality alleviates the free rider problem and leads to increased public good provision. Recently, Baland and Platteau (1997) have challenged the assumption that the group providing the collective good remains stable through time. If

\footnotetext{
${ }^{18}$ For survey on the relationship between ethnic diversity and social capital, see Costa and Kahn (2003a).

${ }^{19}$ For a survey of this topic with a more specific emphasis on economic inequality see La Ferrara (2003b).
} 
members are allowed to quit, increased inequality may worsen the free rider problem for the poor and lead to less collective action because the set of contributors may shrink substantially. Dayton-Johnson and Bardhan (2002) propose a noncooperative model of conservation of common pool resources in which the relationship between asset inequality and economic efficiency is U-shaped. At very low levels of inequality, no one has an incentive to over-exploit the common resource because everyone's share in next period profits is high enough. As inequality increases, more and more poor people will find it convenient to over-exploit the resource because their claims on future profits would be too small. As inequality increases further, the shares of rich players become so high that they will conserve regardless of poor players' behavior, with the extreme result of full efficiency when one player owns the whole resource and free riding is eliminated. In a recent contribution Bardhan, Ghatak and Karaivanov (2002) examine a context in which there are market imperfections in inputs that are complementary to the collective goods: production involves a private and a public good and the marginal gain from contributing to the public good increases with individual endowment of the private good (e.g., with wealth). In this case only people whose wealth exceeds a given threshold will contribute to the provision of the public good, so when assessing the impact of heterogeneity it is important to distinguish between redistributions that occur within the group of contributors and those that occur between contributors and non-contributors. Redistributing wealth from some poor who do not contribute to richer players who do should increase aggregate provision of the public good, in line with Olson's argument. However, if individual contributions are a concave function of wealth, then joint surplus is maximized by equalizing wealth within the group of contributors.

While the above models provide a rather in depth analysis of the ambiguous relationship between collective action and economic inequality, it is not clear to what extent the same conclusions can be generalized to ethnic diversity. The most straightforward extension would be to view each income or wealth category as a separate ethnic group and ask whether changes in income inequality can be viewed as changes in ethnic heterogeneity. Unfortunately the translation is not straightforward. Think for example of a society in which there is one very rich player and $N-1$ equally poor ones. This situation is associated with a high degree of inequality, and according to Olson would lead to a relatively high provision of the public good. However, the above society would not be considered as very heterogeneous in terms of types: out of $N$ people, $N-1$ are exactly equal and there is only one member of the minority group. In other words, the ELF index would classify this situation as one with very low, not very high, ethnic heterogeneity. On the other hand, to the extent that types (e.g., ethnic groups) matter for public good provision only through their contributing capacity, then the inequality framework remains generally applicable. Further research is needed to clarify to what extent the results from the inequality and collective action literature can be applied to the context of ethnic fragmentation, and in particular whether willingness to contribute is the key ingredient to analyze the role of ethnicity in groups, or rather ethnicity operates through 
some other channel.

Partial evidence on the applicability of the collective action framework is provided by recent empirical studies on water irrigation projects. Using data on Mexican irrigation projects, Dayton-Johnson (2000) finds that canal maintenance is worse the more unequal is the distribution of land and the higher is social heterogeneity, proxied by the number of different farming communities represented in the same maintenance unit. Khwaja (2000) uses original data on 132 community-maintained infrastructure projects in Northern Pakistan, the complexity of which ranges from simple irrigation channels to sophisticated electricity units. He finds that both land inequality and inequality in realized project returns have a U-shaped relationship with project maintenance. Furthermore, "social heterogeneity" - measured as the fragmentation into different clans, political and religious groups - is negatively associated with project maintenance. Again, this study suggests that economic inequality and ethnic diversity have similar effects. Compared to other studies, the "message of hope" in Khwaja's empirical results is that good task design seems able to (potentially) compensate for fragmentation in allowing heterogeneous communities to succeed in collective action.

There is also evidence on different mechanisms through which ethnic heterogeneity may harm public good provision. In particular, Miguel and Gugerty (2002) focus on the role played by social sanctions. As we argued in section 2, in environments with weak legal enforcement most informal transactions rely on the availability of "self-enforcing" mechanisms related to repeated interaction and reputation, as well as on the imposition of social sanctions. Miguel and Gugerty assume that such sanctions are more effective if imposed within ethnic groups than between groups. They test this hypothesis using data on 337 primary schools in rural Kenya. In addition to information on students and teachers, their data contains school committee records which report the threat or application of sanctions and the fund raising activities of the school. They find that local ethnic diversity is negatively correlated to school funding and to the quality of school facilities. According to their estimates, moving from complete homogeneity to complete heterogeneity would reduce average local funding by about 20 percent.

An insight into the motivations underlying the failures of collective action in heterogeneous communities is offered by the recent work of Barr (2001). She conducted field experiments in Zimbabwe exploiting the resettlement policies promoted by the government, which generated a set of socially and ethnically heterogeneous villages (treatment) to be compared with non-resettled communities (control). From the results of her trust game, Barr concludes that the lower propensity to trust of resettled villagers is due not to differences in altruism or in socially transmitted norms, but to the lower density of kinship ties. Again, this is consistent with the hypothesis that informal enforcement does not travel well across kinship (and a fortiori ethnic) lines. 


\section{Ethnic fragmentation and endogenous community formation}

In this section we discuss how fragmentation affects not just the economic policies and performance of given communities, but the formation and composition of the relevant communities. In other words, what happens when community size and/or composition can be simultaneously determined with the policies?

\subsection{Countries}

A line of research by Alesina and Spolaore (1997, 2003), Alesina, Spolaore and Wacziarg (2000), Spolaore and Wacziarg (2002) emphasizes the role of racial conflict as a determinant of the number and size of countries. The argument is as follows. The size of a country emerges from a trade off between the benefits of scale (broadly defined) and the cost of heterogeneity of preferences in the population. Benefits of size include economies of scale in the production of some public goods, internalization of policy externalities, the size of the market, defense and protection from foreign aggression, regional insurance schemes. The costs of heterogeneity arise because in large and diverse countries individuals with different preferences have to share common policies so the average utility of these policies is decreasing with heterogeneity. Empirically, racial fragmentation is often associated with differences in preferences, so racial cleavages are a major determinant of the determination of borders, secessions and various centrifugal forces. ${ }^{20}$

A potentially testable implication of this approach is that as the benefits of size diminish, then it becomes more likely that countries can split into more homogenous smaller political entities. One building bloc of this argument is of course that openness to trade is particularly beneficial for small countries. Results by Ades and Glaeser (1999), Alesina, Spolaore and Wacziarg (2000), and Alcala and Ciccone (2003) are all consistent with this hypothesis. To put it another way, this evidence strongly suggests that as trade becomes more open and easy, the benefit of size for economic,growth diminishes. In a completely autharkic world the political size of a country also determines its economic size. In a world of free trade and economic integration, countries can trade with rest of the world, so economic size and political size become more disjoint. That is from an "economic" point of view (our production of private goods in the simple model above) trade makes economic size "larger". On the other hand since countries can retain their independence while trading they do not have to share common public policies on which there are differences of opinions and they do not have to share public goods unrelated to trade. Therefore economic integration should go hand in hand with political disintegration, or to put it differently political centrifugal forces should accompany economic integration. Thus, returning to the question of ethnic fractionalization,

\footnotetext{
${ }^{20}$ Bolton and Roland (1997) explore how income differences and redistribution may lead to break down of countries.
} 
ethnic conflicts can be more easily (at least from an economic point of view) resolved with break down of countries since with free trade even small countries can prosper.

Some insights on this issue can be gathered from the political science literature on partition as a solution to ethnic civil war. In particular, Sambanis (2000) uses a cross sectional data set of all civil wars since 1944, and estimates the probability of partition as a function of the type of civil war (ethnic/religious as opposed to ideological) and of several socio-economic factors, among which ethnic heterogeneity of the population. He finds that the relationship between ethnic diversity and partition depends on the size of the population. While ethnic heterogeneity per se negatively affects the probability of partition, the interaction with population size has a positive coefficient - a result that the author interprets as an indication that large groups are better able to overcome coordination problems. As we shall see below, this result is consistent with some of the arguments put forward to propose the use of indexes of polarization in addition (or as a substitute to) measures of fractionalization.

In addition to economies of scale, another benefit of country size is defense and protection from aggressions, so as the world becomes more peaceful one should observe centrifugal forces. Alesina and Spolaore (2003) discuss historical evidence arguing that this implication is not inconsistent with the data concerning the evolution of country size, international trade and threats of conflicts. Recently, the collapse of the Soviet Union by reducing the threat of and East West conflict has certainly facilitated not only political separatism in Eastern Europe. Huntington (1994) notes how the end of the Cold War allowed the realignment of peoples in to countries that better reflected homogenous "civilizations". In most cases this movement meant breakdown of countries and in a few cases movement toward reunification.

Finally, an important issue is the relationship between ethnic heterogeneity, democracy and country formation. Alesina and Spolaore (2003) discuss the effect of authoritarian systems on measured racial, linguistic or religious fragmentation and country size. Dictators prefer large countries for several reasons. One is that they can extract rents from larger populations, another one is that they can support with size their bellicose attitudes. Historically, one of the main problems of dictators has been to repress racial ethnic conflict in an attempt to create artificially homogeneous countries - an issue to which we return below when we discuss the endogeneity of the notion of fragmentation. In fact often dictators use racial hatred to create support for the dominance of one group over others, a result consistent with models and empirical evidence by Glaeser (2003). One of the implications of this artificial repression of diversity is that centrifugal forces typically explode when dictators falls, as happened for example in the Soviet Union, Spain, Yugoslavia and Iraq. 


\subsection{Cities}

A very large literature (that we cannot even begin to review in any detail) based on the celebrated Tyebout model has discussed the formation and organization of jurisdictions based upon a very simple but powerful idea. The rich want to isolate themselves from the poor to escape from redistributive policies and the poor want to be close to the rich. Until recently virtually all the economic literature on jurisdiction formation in urban economics was based on this income conflict. That is, if the wealthy want to segregate away from the poor, the number of communities would increase as income inequality increases. $^{21}$

On the other hand, a vast body of sociological literature has emphasized the importance of racial divides in the formation and organization of American cities. Alesina, Baqir and Hoxby (2004) provide a model of formation of political jurisdictions which expands upon the models of country formation described above. Again, the formation of local jurisdictions emerges from a trade off between the benefits of scale and the costs of racial heterogeneity. These authors look both at recent evidence and at historical evidence on the formation and break down of school districts, special districts and cities. In particular they consider the Great Migration of African Americans from the South to some areas of the North to support the war industries during the two world wars. They examine how the pattern of jurisdiction formation differs in counties where the immigration of blacks occurred and in those in which did not, confirming the result that the desire for racial homogeneity was driving force of the formation of localities. The trade-off between economies of scale and racial heterogeneity tends to be larger in magnitude and more robust empirically than the trade-off between economics of scale and income heterogeneity.

An important issue is how different dimensions of heterogeneity interact to determine jurisdiction formation. In a recent paper, Sethi and Somanathan (2001) propose a model in which individuals care both about the racial composition of their communities and about its wealth, and in which races differ in income. They show that it is crucial to consider the interplay between preferences on inter-racial interactions and income differentials between races in order to understand patterns of residential location (i.e., segregation). An application of their framework to jurisdiction formation would enrich existing theories in interesting ways.

Heterogeneity can also affect jurisdiction formation through the choice of the "admission rule" into the jurisdiction. Jehiel and Scotchmer (2001) provide a model in which agents are heterogeneous in their taste for a public good, and the choice of the admission rule into the jurisdiction is endogenous. They consider different possible admissions rules (free mobility, majority vote, unanimity, and conditional on demand) and ask which partition is stable for each given rule. While not directly applied to the issue

\footnotetext{
${ }^{21}$ For an excellent recent contribution in this line, which also summarizes much of the earlier work, see Calabrese, Cassidy and Epple (2002).
} 
of ethnic heterogeneity, their theoretical framework seems useful for a research agenda in which changes in ethnic diversity do not automatically translate into break down or consolidation of jurisdictions, but can be mediated through an endogenous choice of specific rules of the game. This seems a promising avenue of research for the future.

\subsection{Groups and networks}

For the sake of exposition, microeconomic models of how heterogeneity affects group formation and composition may be classified under two labels: the preference approach and the consumption approach. According to the preference approach, heterogeneity enters the individual utility function directly, and the impact of increased heterogeneity on an individual's decision to join depends on whether he or she likes or dislikes diversity. According to the consumption approach, on the other hand, heterogeneity affects participation if and only if it affects the quantity or quality of the good provided by the group and/or the cost borne by the individual.

Within the former approach, Alesina and La Ferrara (2000) consider a setting in which individuals prefer to interact with others who are similar to themselves and study under what conditions increased heterogeneity in the population leads to less aggregate participation in groups, even when individuals can sort into multiple homogeneous groups. Using survey data for the US, they find that participation in socio-economic groups is negatively affected by local income inequality, racial fragmentation, and heterogeneity in ethnic origin. Thanks to the availability of direct individual responses on questions regarding racial mixing, they trace the reason for this result to the preference approach: in fact, the negative effect of racial fragmentation on participation only holds for people relatively averse to racial mixing.

Turning to the consumption approach, La Ferrara (2002a) presents a model in which heterogeneous individuals can choose to join a group which provides an excludable good to its members, and derives predictions on the equilibrium composition of the group and on its size under two alternative access rules. The first is one of "open access", by which anyone can join provided he or she pays the cost. The second rule instead allows the members of the group to exclude someone by majority vote. She shows that an increase in heterogeneity has an ambiguous effect both on group composition and on aggregate levels of participation, and that the type of access rule is key in determining what categories are represented in the group. Empirical findings from informal groups in rural Tanzania are consistent with the predictions of the theory.

A growing theoretical literature exists on the formation of networks (see, e.g., the survey by Jackson (2003)). A parallel, mostly empirical, literature has developed on business groups and trade networks in developing areas (see among others the surveys by Khanna (2000) and Rauch (2001)). While a review of that literature goes beyond the scope of this article, a relevant feature of most business groups and networks is that they tend to form along ethnic lines. It would be important to understand to what extent 
exogenous changes in the ethnic composition of a country's business community (e.g., because of trade diasporas) create incentives for further creation and/or segmentation of such groups. For example, in exploring the conditions under which groups are stable with respect to deviations by individuals or coalitions of individuals, it is possible that an increase in members' heterogeneity affects the possibility to form "deviant coalitions", hence the stability of groups themselves.

\section{Open questions}

In this section we highlight the main questions that in our opinion need to be addressed to get a better understanding of how much and why ethnic fragmentation matters.

\subsection{The endogeneity of ethnic diversity}

All the above work shares the assumption that ethnic groups are "objective categories" into which individuals can be classified, and that such classification is commonly shared and exogenous. However, the validity of this assumption can be called into question on several grounds. First, people may not agree on what are the relevant ethnic groups into which they are supposed to "classify" others, i.e., the boundaries of these groups may not be objectively known to all. Secondly, even under the most conventional definition of ethnic fragmentation, the latter may not be determined independently of economic and policy choices at a given point in time. Throughout history rulers have gone a long way to influence (usually reduce) ethnic diversity using a variety of means, from the most extreme ones, ethnic cleansing, to more subtle one, creating costs for various groups to stay. Also to the extent that diversity is measured by language prohibition to use ceratin languages would affect in the long run measures of diversity.

\subsubsection{What makes ethnicity identifiable?}

Underlying all the research we have surveyed so far is the assumption that people's ethnicity is easily identifiable and can be used to construct categories of "homogeneous" individuals. Indeed, the supposed "objective" nature and visibility of ethnic identity is often advocated as the primary reason why economic or political conflict may organize around ethnic lines even when the underlying preferences are not intrinsically about ethnicity. For example, Caselli and Coleman (2002) state that "ethnicity allows groups fighting over resources to enforce membership in the respective coalitions. Without the distinguishing marks of ethnicity, these coalitions would be porous and subject to infiltration". ${ }^{22}$ Fearon (1999) argues that using ethnicity as a criterion for the allocation of "pork" is a way for those who win elections to prevent losers from entering the winning coalition.

\footnotetext{
${ }^{22}$ Caselli and Coleman (2002), p.1.
} 
Several recent contributions, however, have started to challenge this assumption. Horowitz (2001) and Humphreys, Posner and Weinstein (2002) report evidence from case studies in Sri Lanka, Burundi and Ethiopia, where identifying members from different ethnic groups was at times difficult despite the fact that local conflicts were revolving around ethnic roots. In those cases, the possibility to fake one's accent or to dress in a particular way made it impossible to recognize people's ethnic origin even for their local counterparts. In a recent paper, Humphreys and Mohamed (2002) compare the experiences of Mali and Senegal in terms of the ability to identify specific ethnic groups leading separatist movements. They argue that the fact that the Tuaregs and Maures in Mali were relatively "white" compared to the rest of the population led to a polarization of forces and to escalating communal violence. On the other hand, ethnic violence towards the Diola minority group has been limited by the difficulty of identifying them. ${ }^{23}$

In the context of data collection, self reported racial classifications may be partly endogenous to government policies. Users of Census data know how sometimes questions about ethnic affiliation can be a politically charged issue. For example, if the government is known to favor (or hinder) a given ethnic group, people may have an incentive to report (or not report) themselves as part of that group. ${ }^{24}$ How empirically important this "tyranny of the Census" is remains to be seen.

While the notion of endogenous ethnic identity is becoming increasingly popular among social scientists, to our knowledge the only attempt at formalizing it in the context of an economic model is the recent work by Caselli and Coleman (2002). In their model, resources are allocated based on the ethnic composition of the society, and individuals can choose their identity strategically, i.e. can switch ethnicity by paying a cost. The greater the "physical" or cultural distance among the groups, the greater this cost. As we shall see below, this formalization also bears important implications for the building relevant measures of ethnic diversity.

\subsubsection{Why are some ethnic differences perceived as "salient"?}

Ethnic diversity per se is often uncorrelated with economic and political outcomes of interest. For example, compared to the degree of ethnic fragmentation in the African continent, the actual occurrence of conflicts is relatively minor. ${ }^{25}$ Why do ethnic or cultural differences matter in some cases and not in others?

\footnotetext{
${ }^{23}$ Among earlier contributions highlighting the responsiveness of ethnic identities to political and economic incentives, see Anderson (1983) and Horowitz (1985).

${ }^{24}$ Wilkinson (2002) discusses two interesting examples in this respect. One is from a Bohemian town where about a third of the respondents who had declared to be "Germans" in the 1910 Census switched to "Czech" in 1921 to avoid discrimination. The second is from the Indian state of Punjab, where in the 1961 Census the fraction of Punjabi speakers dropped by over 20 percentage points because many Hindu Punjabi speakers who wanted to block the attempts of a Sikh movement to partition the state declared themselves as speaking Hindi.

${ }^{25}$ Based on the estimates of Fearon and Laitin (1996), only one violent conflict actually occurs for every 2,000 instances that would be predicted based on ethnic fragmentation.
} 
Posner (2002) offers an interesting "natural experiment" originated from the arbitrary drawing of the border between Zambia and Malawi. When the border between the two countries was drawn, two ethnic groups -the Chewas and the Tumbukas- were partitioned so that approximately two thirds of each group remained in Malawi, and the rest in Zambia. Coming from an identical cultural background, the evolution over time of the relationship between the two ethnic groups in each country can be presumed to be the result of the difference in economic and political institutions. In particular, since their division the Chewas and the Tumbukas have been political allies in Zambia and adversaries in Malawi. Posner (2002) suggests that the explanation for this difference lies in the relative size of each group compared to the relevant country's population. While in Malawi both groups represent a large fraction of the country's population, hence they can compete for power at the national level, in Zambia they are a minority compared to other ethnic groups and they often ally as an "Eastern" coalition against the remaining political forces. This example powerfully suggests that there is nothing intrinsic to physical differences or to the content of cultural traditions that should make a given ethnic divide "salient" or not: rather, it is the structure of domestic political and economic competition that shapes potential ethnic divisions into meaningful realities.

As a matter of fact, even within a given institutional structure the salience of ethnic divisions can change over time as a response to politico-economic incentives. Alesina et al. (2003) discuss the example of Somalia, which until the onset of the 1991 civil war was considered an ethnically homogeneous country because 85 percent of the population was Somali. The war shifted the relevant dimension of ethnic cleavage to that of "clans", and individual self-identification to groups changed in a way that made the country more "ethnically" fragmented. Fearon (2003) argues that the only way to really measure ethnic fragmentation is to get the salient issue "right" that is to identify correctly for every country what the salient divisions are.

\subsubsection{Mobility and ethnic fragmentation}

Finally, even if one were ready to accept the definition of ethnic groups as objective categories with exogenous borders, we should worry about the potential endogeneity of ethnic diversity measures as a result of individual mobility. Consider for example US cities. Changes over time in the economic growth of different metropolitan areas have induced massive flows of migration that have sensibly altered some cities' ethnic composition. Local economic policies have also played a role: the structure of public policies such as education spending is such that the racial or ethnic composition of a given area can also shift over time as a result of policy changes. An empirical solution to this issue is provided for example by Alesina, Baqir and Hoxby (2004), who use historical evidence on the pattern of South-North migration to develop the war industry in the early XX century as an instance of pre-determined local ethnic composition.

In a cross country setting, endogeneity of ethnic differences due to geographic mo- 
bility is less likely to be relevant, except possibly as a result of diasporas following civil wars. However, other indexes of heterogeneity employed in cross country regressions may present problems. An interesting example of this issue has to do with measures of religious fragmentation, a variable recently brought to the forefront of growth empirics by Barro and Mc Leary (2002). Alesina et al. (1993) show that the religious fragmentation are generally positively correlated to "good" policy outcomes, the opposite of the correlation found on ethnic fragmentation measures. The explanation is precisely the endogeneity of religious fragmentation: countries with more fragmentation are the more tolerant ones, whereas in many cases religious uniformity is imposed from the top by coercive regimes.

\subsection{Measuring ethnic diversity}

\subsubsection{What dimension of heterogeneity?}

How to classify ethnic groups is a difficult and politically charged issue. While for the US the Census Bureau provides a classification in five major groups which is fairly broadly accepted, similar classifications for other countries are more problematic. Individuals differ in skin color, language, origin of birth, religion: in some countries language is the key dividing line, in others it is skin color. What dimension should one use? Can ethnicity be measured in a multidimensional way?

The raw data originally used by Easterly and Levine (1997) come from the Atlas Narodov Mira, a compilation of ehtnolinguistic groups present in 1960 based on historical linguistic origin. A first weakness of this data is that linguistic heterogeneity does not necessarily coincide with ethnic heterogeneity. For instance, most Latin American countries are relatively homogenous in terms of language but less so in terms of "ethnicity" or "race". Fearon (2003) and Alesina et al. (2003) have compiled various measures of ethnic heterogeneity which try to tackle the fact that the difference amongst groups manifests itself in different ways in different places. The two classifications are constructed differently. Alesina et al. (2003) do not take a stand on what ethnicity (or language or religion) are more salient than others and adopt the country breakdown suggested by original sources, mainly the Encyclopedia Britannica (See the Appendix for more details). Fearon (2003) instead is trying to construct the "right list" of ethnic groups which "depends on what people in the country identify as the most socially relevant ethnic groupings" (page 198). This approach has the advantage of being closer to what the theory would want and the disadvantage of having to make judgement calls (or adopt others' judgement calls) about what is the "right list". The sources used by Fearon (2003) are carefully described in his paper, but an especially useful one to identify "salient" cases of ethnic conflict is Gurr (1996) who classifies minorities at risk in many countries around the world.

Alesina et al. (2003) identify language groups as well as ethnic groups that are defined by other characteristics, such as skin color. The correlation between their more 
comprehensive $E L F$ index and the one based purely on language is between 0.6 and 0.7 , depending on the period and sample of countries. An interesting example of the differences between the two indices is Latin America. In this region the language index shows more homogeneity because the language of the former colonizers (Spanish, Portuguese, English) is often spoken by most, but the index based on skin color or ethnic origin (say black, mulattos, white, mestizos, Indian, etc.) shows more heterogeneity. The correlation between the Alesina et al. (2003) measure of ethnic fragmentation and Fearon's (2003) is about 0.76. It is therefore quite high but the two are not quite the same variable, as they should not given the different criteria of construction.

Recent work by Nopo, Saavedra and Torero (2002) takes an innovative approach by using survey data in which every respondent is assigned a score from 1 to 10 for each of the four main racial groups in Peru: White, Indigenous, Black, and Asian. This way heterogeneity can be measured through a multidimensional index of "racial intensity". It should be explored to what extent it is feasible, and profitable, to move in this direction.

A second weakness of the Atlas data has to do with the way in which the various groups were formed. Posner (2003) argues that the Atlas data suffers from a "grouping problem" at two different levels. On the one hand, many groups are aggregated into a single category while they are distinct political actors - even enemies- at the national level. The most striking example of this concerns the Tutsis and the Hutus in Rwanda, which are aggregated into a single category "Banyrwanda". At the opposite extreme stand a number of groups that are listed as separate linguistic categories, but whose distinction has no political or economic relevance. Posner (2003) thus proposes a classification based on "politically relevant ethnic groups" (PREG), defined as groups that can influence economic policy decisions either directly or indirectly (e.g., by threatening to remove politicians from power). However, it is difficult to argue that the realized structure of power at a given point in time is exogenous and can be used as an underlying determinant of the definition of ethnic groups. To date, it is still unclear how to integrate linguistic or "ethnic" differences with other dimensions that make the latter politically or economically salient.

\subsubsection{What index?}

Most of the existing literature on ethnic diversity and economic performance focuses on the "fractionalization index" defined by expression (8) in section 3.1. This index captures the probability that two individuals randomly drawn from the population belong to different groups, and reaches a theoretical maximum of 1 when every individual belongs to a different group. This measure implies that a country composed by say 100 equally sized groups is more fractionalized than a country with two equally sized groups. However, an argument that goes back as far as the Founding Fathers is that a country composed by many small groups may actually be more stable than one composed by 
two equally sized ones, which are more likely to be in direct conflict with each other. ${ }^{26}$ Based upon the theoretical results of Esteban and Ray (1994), Garcia-Montalvo and Reynal-Querol (2002a) propose the following "polarization index":

$$
R Q=1-\sum_{i=1}^{N}\left(\frac{1 / 2-s_{i}}{1 / 2}\right)^{2} s_{i} .
$$

where $s_{i}$ is the share of group $i$ in the population. The index $R Q$ reaches maximum when two equally sized groups face each other and declines as the configuration of groups differs more and more from this half and half split. The authors also show that this index is highly correlated with ethnolinguistic fractionalization $(E L F)$ at low levels of $E L F$, uncorrelated at intermediate levels, and negatively correlated at high levels. In a cross country regression analysis, they find that ethnic polarization has a positive impact on the likelihood that a civil war occurs, and a negative effect on a country's growth rate. They do not find an independent effect of ethnic fractionalization. Using a different data set, Alesina et al. (2003) compare the results of the polarization index $R Q$ and the fractionalization index $E L F$, and find that fractionalization works slightly better as a determinant of policies and economic outcomes. While the apparent inconsistency between the two sets of results may be due partly to different parameterization and partly to different data sources, it is difficult to gauge the statistical significance of the difference due to the high correlation between the two measures at low levels of fragmentation.

Another important issue is whether all groups should be treated symmetrically, as they are in the fragmentation index and to an extent in the polarization index. ${ }^{27}$ Alternatively, one may want to assign weights to the distance between groups, as suggested for example by the theory of Caselli and Coleman (2002). While in principle the latter approach seems the right one in a variety of policy applications, it is extremely difficult to envisage a way of implementing it. One possibility to measure distance would be to use differences in average income between groups. This is an approach followed by work in progress by Aghion, Alesina and Trebbi (2004) for US cities.

\footnotetext{
${ }^{26}$ Madison (Federalist Papers n. 11) used this argument to convince skeptics that a multi-ethnic Unites States was viable, precisely because a complex web of cross group cleavages would make it more stable. Whether or not the history of the US with the Civil War confirmed Madison's views is a much debated question.

${ }^{27}$ In the formula for $R Q$ the deviation of each group from the maximum polarization share of 0.5 is weighted by the group's own share. However, underlying that formula is the assumption that the "distance" between each group (continuous, as originally conceived by Esteban and Ray (1994)) is discrete and it is the same.
} 


\section{Conclusions and policy implications}

What are the policy implications of all of the above? The issue is quite difficult and politically charged and it is relevant in at least two areas: immigration policies and local policies that may increase or decrease racial integration. The implication of promoting racial homogeneity is unappealing and probably incorrect both in the short and in the long run. Laitin (1994) provides an interesting example concerning language in Ghana. After independence this country faced the question of which language to adopt as the official one. Using English had the advantage of being understood by most and of not favoring one ethnic group over another. On the other hand it was the language of a colonizer. Laitin argues that a solution with multiple languages may dominate that of a single homogenous language. The benefit of homogeneity had to be traded off against other considerations (national pride, ethnic balance; etc.).

Globalization also has important implications for ethnic politics. To the extent that small countries can prosper in a world of free trade, then peaceful separatism of certain minorities should not be viewed as threatening, at least from an economic point of view. As far as domestic social policy is concerned, the question is to what extent favoring racial mixing (say with affirmative action) promotes harmony, an issue that would require an entire separate paper. The starting point would be Lijphart's (1977) seminal contribution that provides a notion of power sharing denoted as "consociational democracy". The key features of this type of democracy should be a coalition government in which "all significant segments of the plural society" 28 are represented, with a proportionality system, a mutual veto, and a federalist structure. He highlights the conditions under which power sharing is likely to succeed, namely, a relative balance of power and economic equality among the different groups. Most importantly, he argues that different groups are most likely to find an agreement when they have to face external threats. This makes power sharing schemes difficult to implement and ultimately unstable in some developing countries (e.g., Africa) where most threats to the State come from within. Among recent examples of power sharing agreements that have failed due to internal conflicts are those of Angola and Rwanda. On the other hand, South Africa and Somaliland have managed to successfully implement consociationalist schemes. Spears (2002) reports that, in addition to the presence of an "external" threat (Mogadishu), in the case of Somaliland a deeply rooted tradition of power sharing among the elders of local clans may have contributed to the viability of such schemes. However, this calls into question the effectiveness of power sharing as a means of generating inter-ethnic cooperation: indeed power sharing may well be the result of pre-existing attitudes towards inter-ethnic cooperation.

With this survey we have tried to asses costs and benefits of ethnic fragmentation and the policy issues arising in diverse societies. In a more and more integrated world, the question of how different people can peacefully interact is the critical problem for

\footnotetext{
${ }^{28}$ Lijphart (1977), p.25.
} 
the next many decades.

\section{References}

[1] Ades A. and E Glaeser (1995), "Trade and circuses: explaining urban giants", Quarterly Journal of Economics, 122, 195-228.

[2] Aghion, P., A. Alesina and F. Trebbi (2002), "Endogenous Political Institutions", NBER Working Paper

[3] Aghion P. A Alesina and F. Trebbi (2004) "Polarization and Institutional Choice" unpublished

[4] Alcala, F. and A. Ciccone (2004), "Trade and productivity" Quarterly Journal of Economics forthcoming

[5] Alesina, A., R. Baqir and W. Easterly (1999), "Public Goods and Ethnic Divisions", Quarterly Journal of Economics, 114 (4), 1243-1284.

[6] Alesina, A., R. Baqir and C. Hoxby (2004), "Political Jurisdictions in Heterogeneous Communities", Journal of Political Economy, forthcoming.

[7] Alesina, A., A. Devleschawuer, W. Easterly, S. Kurlat and R. Wacziarg (2003), "Fractionalization", Journal of Economic Growth, 8, 155-94

[8] Alesina, A. and E. Glaeser (2004), Fighting poverty in the US and Europe: a world of difference, Oxford University Press, forthcoming.

[9] Alesina A. E. Glaeser and B. Sacerdote (2001), "Why Doesn't the US Have a European Style Welfare State?" Brookings Papers on Economic Activity, Fall.

[10] Alesina A. and E. La Ferrara (2002), "Who Trust Others?" Journal of Public Economics, August.

[11] Alesina, A. and E. La Ferrara (2000), "Participation in Heterogeneous Communities", Quarterly Journal of Economics, 115 (3), 847-904.

[12] Alesina, A. and E. Spolaore (1997), "On the Number and Size of Nations," Quarterly Journal of Economics, 112 (4), 1027-56.

[13] Alesina, A., E. Spolaore and R. Wacziarg (2000), "Economic Integration and Political Disintegration", American Economic Review, 90

[14] Alesina A. and R. Wacziarg (1998), "Openness, Country Size and Government", Journal of Public Economics, vol. 69, no. 3, September, p. 305-321. 
[15] Anderson, B. (1983), Imagined Communities, London: Verso.

[16] Arcand, J.-L., P. Guillaumont and S. Guillaumont Jeanneney (2000), "How to Make a Tragedy: On the Alleged Effect of Ethnicity on Growth", Journal of International Development, 12, 925-938.

[17] Baland, J.-M., O. Dagnelie and D. Ray (2002), "Inequality and inefficiency in joint projects", mimeo, University of Namur.

[18] Baland, J.-M., Platteau, J.-P. (1997), "Wealth inequality and efficiency in the commons, Part I: The unregulated case", Oxford Economic Papers, 49, 451-482.

[19] Bardhan, P.(2000), "Irrigation and cooperation: An empirical analysis of 48 irrigation communities in South India", Economic Development and Cultural Change, $48,847-865$.

[20] Bardhan, P., Ghatak, M., Karaivanov, A. (2002), "Inequality, market imperfections, and the voluntary provision of collective goods", mimeo, UC Berkeley.

[21] Barr, A. (2001), "Kinship, Familiarity and Trust: An Experimental Investigation", unpublished, CSAE Oxford.

[22] Barro R. and R. Mc Leary (2002), "Religion and Political Economy in an International Panel", NBER Working Paper 8931.

[23] Biggs, T., M. Raturi, and P. Srivastava (2002), "Ethnic Networks and Access to Credit: Evidence from the Manufacturing Sector in Kenya", Journal of Economic Behavior and Organization, 49, 473-486.

[24] Bigsten, A., P. Kimuyu, and K. Lundvall (2000), "Informality, Ethnicity, and Productivity. Evidence from Small Manufacturers in Kenya", Dept. of Economics Working Paper 27, Goteborg University.

[25] Blanchard O. and L. Katz (1992) "Regional Evolutions" Brookings Papers on Economic Activity, 1, 1-76

[26] Bolton P and G. Roland (1997) "The break up of Nations: A Political economic analysis" Quarterly Journal of Economics, 1057-80

[27] Burns N. (1994) The Formation of American Local Governments Oxford University Press, New York

[28] Calabrese, S., G. Cassidy and D. Epple (2002), "Local governments, fiscal structure and metropolitan consolidation", in W.G. Gale and J. Rothenberg Pack (eds.), Brooking Wharton Papers on Urban Affairs 2002. 
[29] Canning, D. and M. Fay (1993), "The Role of Infrastructures in Economic Growth", unpublished.

[30] Casella, A. and J. Rauch (Eds.), (2001), Networks and Markets, Russell Sage Foundation.

[31] Casella, A. and J. Rauch, (2003), "Overcoming Informational Barriers to International Resource Allocation: Prices and Ties", Economic Journal, 113, 21-42.

[32] Caselli, F. and J. Coleman (2002), "On the Theory of Ethnic Conflict", unpublished, Harvard University.

[33] Central Intelligence Agency (2000) CIA World Factbook CIA Printing Office Washington $\mathrm{C}$

[34] Conley, J.P. and M. Wooders (1996), "Taste-Homogeneity of Optimal Jurisdictions in a Tiebout Economy with Crowding Types and Endogenous Educational Investment Choices", Ricerche Economiche, 50(4), 367-87.

[35] Collier, P. and J.W. Gunning (1999), "Explaining African Economic Performance", Journal of Economic Literature, 37, 64-111.

[36] Collier P. (2000) "Ethnicity, Politics and Economic Performance" Economics and Politics 12, 225-45.

[37] Collier P. (2001)' Implications of Ethnic Diversity' Economic Policy 32 129-66.

[38] Collier P and JW Gunning (1999) "Explaining Africa's Economic Performance" Journal of Economic Literature, 37, 64-111

[39] Collier P. and A Hoeffler (1998) " On the economic causes of civil wars" Oxford Economic Papers 50, 563-73.

[40] Collier P., and A. Hoeffler (2002), "Greed and grievance in civil wars", Working Paper, The World Bank.

[41] Costa D. and M. Kahn (2003a), "Civic Engagement in heterogeneous Communities" Perspectives on Politics 103-112.

[42] Costa D. and M. Kahn (2003b), "Understanding the decline in American Social Capital", Kyklos, 17-46.

[43] Dayton-Johnson, J. (2000), "The determinants of collective action on the local commons: A model with evidence from Mexico", Journal of Development Economics, 62(1), 181-208. 
[44] Dayton-Johnson, J. and P. Bardhan (2002), "Inequality and conservation on the local commons: A theoretical exercise", Economic Journal, 112(481), 577-602.

[45] Easterly, W. (2001), "Can Institutions Resolve Ethnic Conflict?", Economic Development and Cultural Change, 49(4), 687-706.

[46] Easterly W. and R. Levine (1997), "Africa's Growth Tragedy: Policies and Ethnic Divisions", Quarterly Journal of Economics, 111(4), 1203-1250.

[47] Esteban, J-M. and D. Ray, (1994), "On the Measurement of Polarization", Econometrica, 62(4), 819-851.

[48] Fafchamps, M. (2000), "Ethnicity and Credit in African Manufacturing", Journal of Development Economics, 61, 205-235.

[49] Fearon, J. (1999), "Why Ethnic Politics and "Pork" Tend to Go Together", unpublished, Stanford University.

[50] Fearon J. (2002), "Fractionalization and civil wars", unpublished, Stanford University.

[51] Fearon, J. (2003), "Ethnic and Cultural Diversity by Country," Journal of Economic Growth, 8(2), 195-222.

[52] Fearon, J. and D. Laitin (1996), "Explaining inter Ethnic Cooperation", American Political Science Review, 90, 715-29.

[53] Fisman, R. (1999), "Trade Credit and Productive Efficiency in Developing Economies", mimeo, Columbia University.

[54] Fisman, R. (2003), "Ethnic Ties and the Provision of Credit: Relationship-Level Evidence from African Firms", Advances in Economic Analysis and Policy, 3(1), Article 4.

[55] Florida, R. (2002a), "Bohemia and Economic Geography", Journal of Economic Geography, 2, 55-71.

[56] Florida R. (2002b) "The Economic Geography of Talent" Annals of the Association of American Geographers 743-55.

[57] Garcia-Montalvo, J. and M. Reynal-Querol (2002), "Why Ethnic Fractionalization? Polarization, Ethnic Conflict and Growth", unpublished, Universitat Pompeu Fabra.

[58] Genicot, G. and D. Ray (2003), "Group formation in risk sharing arrangements", Review of Economic Studies, 70(1). 
[59] Glaeser, E.(2002), "The Political Economy of Hatred", unpublished, Harvard University.

[60] Glaeser, E., J. Scheinkman, and A. Shleifer (1995), "Economic Growth in a Cross Section of Cities," Journal of Monetary Economics, 36(1), 117-43.

[61] Goldin, C., and L. Katz (1999), "Human Capital and Social Capital: The Rise of Secondary School in America, 1910 to 1940", Journal of Interdisciplinary History, 29, 683-723.

[62] Greif, A. (1993), "Contract Enforceability and Economic Institutions in Early Trade: The Maghribi Traders' Coalition", American Economic Review, 83(3), 525548.

[63] Gurr T (1996) Minorities at risk dataset University of Maryland.

[64] Horowitz, D.L. (1985), Ethnic Groups in Conflict, Berkeley, CA: University of California Press.

[65] Horowitz, D.L. (2001), The Deadly Ethnic Riot, Berkeley, CA: University of California Press.

[66] Humphreys, M., D.N. Posner and J.M. Weinstein (2002), "Ethnic Identity, Collective Action, and Conflict: An Experimental Approach", unpublished, Harvard University and UCLA.

[67] Huntington S. (1994) The clash of civilizations

[68] Jackson, M.O. (2003), "A Survey of Models of Network Formation: Stability and Efficiency", mimeo, California Institute of Technology.

[69] Jehiel, P. and S. Scotchmer (2001), "Constitutional Rules of Exclusion in Jurisdiction Formation," Review of Economic Studies, 68 (2), 393-413.

[70] Karlan, D. (2003), "Social Capital and Group Banking", mimeo, Princeton University.

[71] Keefer and Knack (2000), "Polarization, Politics, and Property Rights: Links between Inequality and Growth", Policy Research Working Paper 2418, The World Bank.

[72] Khanna, T. (2000), "Business Groups and Social Welfare in Emerging Markets: Existing Evidence and Unanswered Questions", European Economic Review, 44, 748-761. 
[73] Khwaja, A. (2000), "Can good projects succeed in bad communities? Collective action in the Himalayas", mimeo, Harvard University.

[74] La Ferrara, E. (2002a), "Inequality and Participation: Theory and Evidence from Rural Tanzania", Journal of Public Economics, 85(2), 235-273.

[75] La Ferrara, E. (2002b), "Self-help groups and income generation in the informal settlements of Nairobi", Journal of African Economies, 11(1), 61-89.

[76] La Ferrara, E. (2003a), "Kin Groups and Reciprocity: A Model of Credit Transactions in Ghana", American Economic Review, December.

[77] La Ferrara E. (2003b) "Solidarity in Heterogeneous Communities" in Cultural Diversity versus Economic Solidarity, Francqui Scientific Library, Brussels Deboeck Universite'

[78] La Porta R., F. Lopez de Silanes, A. Shleifer and R. Vishny (1999), "The Quality of Government", Journal of Law, Economics and Organization, vol. 15, no. 1, March, 222-279.

[79] Laitin D (1994) "The tower of babel as a coordination game: political linguistic in Ghana" American Political Science Review 622-34.

[80] Lazear E (1999a) "Globalization and the market for team-mates" Economic Journal 109, 15-40.

[81] Lazear E. (1999b) "Culture and Language" Journal of Political Economy ,Supplement, 95-125

[82] Lee W. and J. Roemer (2003) "Racism and redisitribution in the United States: A solution to the problem of American exceptionalism" unpublished

[83] Levinson D. (1998) Ethnic Groups World Wide Oryx Press Phoenix

[84] Lijphart, A. (1977), Democracy in Plural Societies: A Comparative Exploration, New Haven: Yale University Press.

[85] Lijphart, A. (1999), Patterns of Democracy, New Haven: Yale University Press.

[86] Luttmer, E. (2001), "Group Loyalty and the Taste for Redistribution," Journal of Political Economy, 109, 500-28.

[87] Martinez-Vazquez, J., M. Rider and M.B. Walker (1997), "Race and the Structure of School Districts in the United States", Journal of Urban Economics, 41, 281-300. 
[88] Mauro P. (1995), "Corruption and Growth", Quarterly Journal of Economics, vol. 110, no. 3, August, 681-712.

[89] Nopo, H., J. Saavedra and M. Torero (2002), "Ethnicity and earnings in urban Peru", mimeo, GRADE.

[90] Olson, M. (1965), The logic of collective action, Harvard University Press, Cambridge, MA.

[91] O' Reilly C., K. Williams and S. Barsade (1997) "Demography and group performance" unpublished

[92] Ottaviano, G. and G. Peri (2003), "The Economic Value of Cultural Diversity", mimeo, UC Davis.

[93] Posner, D.N. (2003), "Measuring Ethnic Fractionalization in Africa," American Journal of Political Science, forthcoming.

[94] Posner, D.N. (2002), "The Political Salience of Cultural Difference: Why Chewas and Tumbukas Are Allies in Zambia and Adversaries in Malawi", unpublished, UCLA.

[95] Poterba, J. (1997), "Demographic Structure and the Political Economy of Public Education", Journal of Policy Analysis and Management, 16(1), 48-66.

[96] Pratt A. (2000) "Should a team be homogeneous?" unpublished

[97] Rauch, J.E. (2001), "Business and Social Networks in International Trade", Journal of Economic Literature, 39, 1177-1203.

[98] Reynal-Querol, M. (2002), "Ethnicity, Political Systems and Civil Wars", Journal of Conflict Resolution, 46(1), 29-54.

[99] Sambanis, N. (2000), "Partition as a Solution to Ethnic War: An Empirical Critique of the Theoretical Literature", World Politics, 52(4), 437-483.

[100] Sethi, R. and R. Somanathan (2001), "Inequality and Segregation", mimeo, Columbia University.

[101] Spears, I.S. (2002), "Africa: The Limits of Power Sharing", Journal of Democracy, $13(3), 123-136$.

[102] Spolaore, E. and R. Wacziarg (2002), "Borders and Growth", unpublished, Stanford University.

[103] Tajfel, H., M. Billig, R.P. Bundy and C. Flament (1971), "Social Categorization and Intergroup Behavior", European Journal of Social Psychology, 1, 149-178. 
[104] Vigdor J. (2004) "Community Composition and Collective Action:Analyzing Initial mail responses to 2000 Census" Review of Economics and Statistics, forthcoming

[105] Wilkinson, S. (2002), "Memo on Developing Better Indicators of Ethnic and Non Ethnic Identities", presented at LICEP 5th Meeting, Stanford University. 


\section{Data Appendix}

The data we use in this paper come from Alesina, Devleshawuer, Easterly, Kurlat and Wacziarg (2003). The authors use the Encyclopedia Britannica (2001). The variable "language" that underlies the fractionalization index based on it, refers to "the shares of languages spoken as mother language based upon national census data." Other sources for language data are the CIA World Factbook (which however is available for only a smaller set of countries) and the Ethnologue project that lists approximately 6,800 languages. Alesina et al. (2003) report that fractionalization for languages based upon these alternative sources are highly correlated with Encyclopedia Britannica.

The variable ethnic fractionalization combines the language variable above with other information about racial characteristics (normally skin color). Groups were classified as different if they spoke a different language and/or had different physical characteristics. Sources for physical differences were the Encyclopedia Britannica, CIA Factbook (2000) for 25 countries, Levinson (1998) for 23 countries and Minority Rights Group International (1997) for 13 cases. The rule used for data collection was: "if two or more sources for the index of ethnic fractionalization were identical to the third decimal point, we used these sources (the recorded source in this case was normally Encyclopedia Britannica). If sources diverged up to the second decimal point, we used the source were reported ethnic groups covered the largest share of the population"..The resulting ethnicity data covers 650 different ethnic groups in 190 countries, and is available on the web. 
Table 1: Fractionalization and Long-run growth

(dependent variable is growth of per capita GDP)

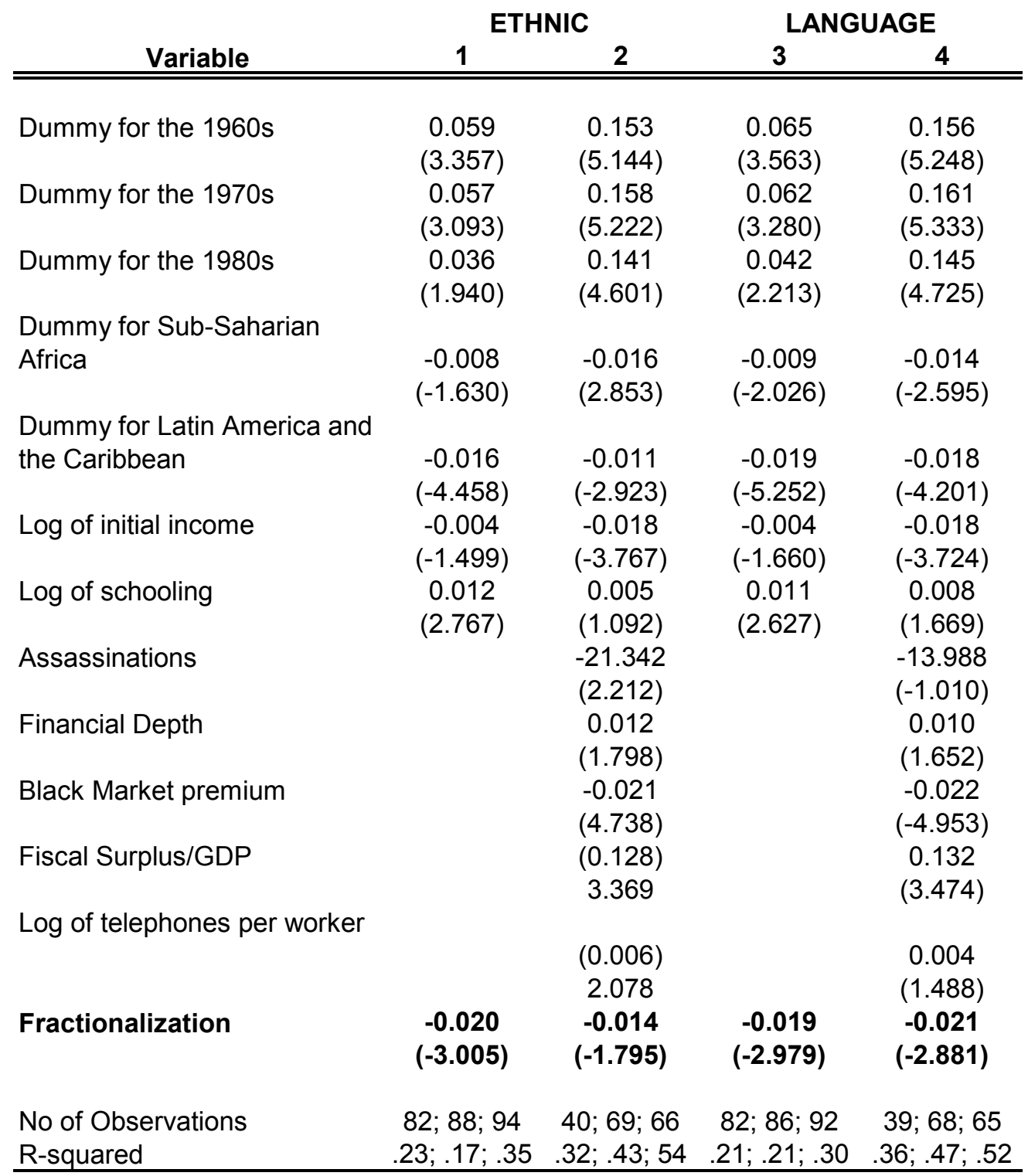

(t-statistics in parentheses)

Estimated using Seemingly Unrelated Regressions: a separate regression for each 10 year period. 
Table 2: Fractionalization and Long-run growth

(dependent variable is growth of per capita GDP)

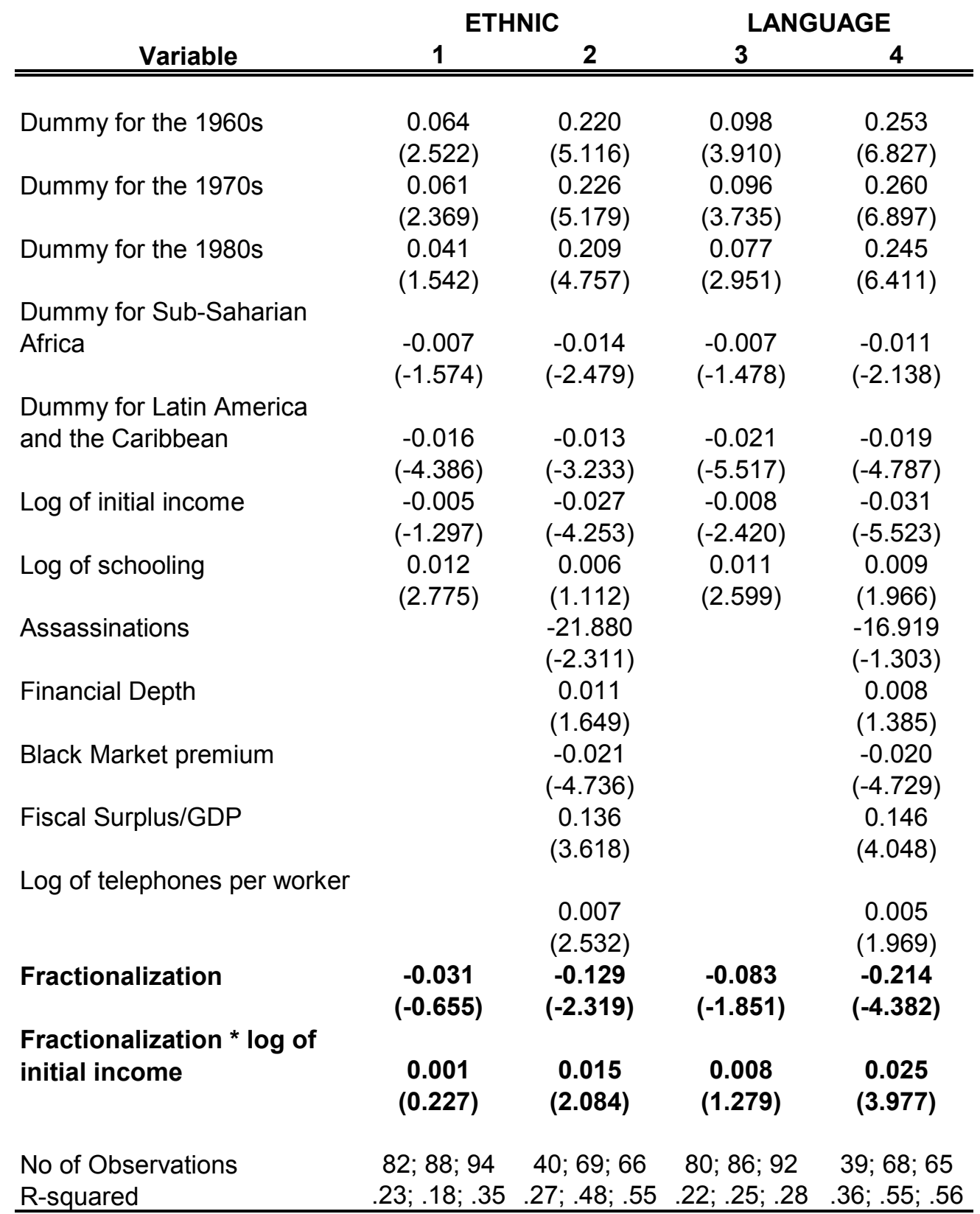

(t-statistics in parentheses)

Estimated using Seemingly Unrelated Regressions: a separate regression for each 10 year period. 
Table 3: Fractionalization, Democracy and Long-run growth (dependent variable is growth of per capita GDP)

\begin{tabular}{|c|c|c|c|c|}
\hline \multirow{2}{*}{ Variable } & \multicolumn{2}{|c|}{ ETHNIC } & \multicolumn{2}{|c|}{ LANGUAGE } \\
\hline & 1 & 2 & 3 & 4 \\
\hline Dummy for the 1960s & $\begin{array}{c}0.059 \\
(3.290)\end{array}$ & $\begin{array}{c}0.153 \\
(5.090)\end{array}$ & $\begin{array}{c}0.073 \\
(3.897)\end{array}$ & $\begin{array}{c}0.159 \\
(5.331)\end{array}$ \\
\hline Dummy for the 1970s & $\begin{array}{c}0.056 \\
(2.869)\end{array}$ & $\begin{array}{c}0.155 \\
(4.983)\end{array}$ & $\begin{array}{c}0.069 \\
(3.418)\end{array}$ & $\begin{array}{c}0.162 \\
(5.220)\end{array}$ \\
\hline Dummy for the 1980s & $\begin{array}{c}0.035 \\
(1.790)\end{array}$ & $\begin{array}{c}0.137 \\
(4.358)\end{array}$ & $\begin{array}{c}0.050 \\
(2.420)\end{array}$ & $\begin{array}{c}0.146 \\
(4.632)\end{array}$ \\
\hline Dummy for Sub-Saharia & & & & \\
\hline Africa & $\begin{array}{l}-0.008 \\
(-1.628)\end{array}$ & $\begin{array}{l}-0.014 \\
(-2.493)\end{array}$ & $\begin{array}{l}-0.006 \\
(-1.371)\end{array}$ & $\begin{array}{l}-0.010 \\
(-1.805)\end{array}$ \\
\hline $\begin{array}{l}\text { Dummy for Latin Americ } \\
\text { and the Caribbean }\end{array}$ & $\begin{array}{l}-0.016 \\
(-4.521)\end{array}$ & $\begin{array}{c}-0.012 \\
(-3.017)\end{array}$ & $\begin{array}{l}-0.020 \\
(-5.324)\end{array}$ & $\begin{array}{l}-0.017 \\
(-4.087)\end{array}$ \\
\hline Log of initial income & $\begin{array}{l}-0.004 \\
(-1.619)\end{array}$ & $\begin{array}{l}-0.019 \\
(-3.933)\end{array}$ & $\begin{array}{l}-0.006 \\
(-2.274)\end{array}$ & $\begin{array}{l}-0.019 \\
(-4.029)\end{array}$ \\
\hline Log of schooling & $\begin{array}{c}0.012 \\
(2.842)\end{array}$ & $\begin{array}{c}0.007 \\
(1.351)\end{array}$ & $\begin{array}{c}0.013 \\
(3.108)\end{array}$ & $\begin{array}{c}0.010 \\
(1.959)\end{array}$ \\
\hline Assassinations & & $\begin{array}{l}-23.495 \\
(-2.423)\end{array}$ & & $\begin{array}{l}-14.057 \\
(-1.045)\end{array}$ \\
\hline Financial Depth & & $\begin{array}{c}0.012 \\
(1.951)\end{array}$ & & $\begin{array}{c}0.012 \\
(1.897)\end{array}$ \\
\hline Black Market premium & & $\begin{array}{l}-0.021 \\
(-4.828)\end{array}$ & & $\begin{array}{l}-0.023 \\
(-5.169)\end{array}$ \\
\hline Fiscal Surplus/GDP & & $\begin{array}{c}0.117 \\
(3.060)\end{array}$ & & $\begin{array}{c}0.131 \\
(3.520)\end{array}$ \\
\hline Log of telephones per $w$ & & $\begin{array}{c}0.006 \\
(2.185)\end{array}$ & & $\begin{array}{c}0.004 \\
(1.610)\end{array}$ \\
\hline Fractionalization & $\begin{array}{c}-0.014 \\
(-1.856)\end{array}$ & $\begin{array}{l}-0.002 \\
(-0.233)\end{array}$ & $\begin{array}{l}-0.017 \\
(-2.187)\end{array}$ & $\begin{array}{l}-0.008 \\
(-0.877)\end{array}$ \\
\hline Democracy & $\begin{array}{c}0.001 \\
(0.867)\end{array}$ & $\begin{array}{c}0.003 \\
(1.833)\end{array}$ & $\begin{array}{c}0.002 \\
(1.390)\end{array}$ & $\begin{array}{c}0.002 \\
(2.064)\end{array}$ \\
\hline Fractionalization * & & & & \\
\hline Democracy & $\begin{array}{c}-0.002 \\
(-1.230)\end{array}$ & $\begin{array}{l}-0.005 \\
(-1.871)\end{array}$ & $\begin{array}{l}-0.003 \\
(-1.885)\end{array}$ & $\begin{array}{l}-0.005 \\
(-2.489)\end{array}$ \\
\hline
\end{tabular}

No of Observations $\quad 82 ; 87 ; 93 \quad 40 ; 69 ; 66 \quad 80 ; 85 ; 90 \quad 39 ; 68 ; 65$

\begin{tabular}{llllll}
$\mathrm{R}$-squared & $.23 ; .19 ; .34$ & $.33 ; .46 ; .53$ & $.21 ; .26 ; .27$ & $.35 ; .52 ; .52$ \\
\hline
\end{tabular}

(t-statistics in parentheses)

Estimated using Seemingly Unrelated Regressions: a separate regression for each 10 year period. 
Table 4: Fractionalization, Democracy and Long-run growth (dependent variable is growth of per capita GDP)

\begin{tabular}{lcc}
\multicolumn{1}{c}{ Variable } & $\mathbf{1}$ & $\mathbf{3}$ \\
\hline \hline & 0.118 & 0.138 \\
Dummy for the 1960s & $(4.689)$ & $(5.593)$ \\
& 0.115 & 0.135 \\
Dummy for the 1970s & $(4.356)$ & $(5.197)$ \\
& 0.096 & 0.117 \\
Dummy for the 1980s & $(3.562)$ & $(4.426)$ \\
& & \\
Dummy for Sub-Saharian & -0.005 & -0.003 \\
Africa & $(-1.053)$ & $(-0.668)$ \\
& & \\
Dummy for Latin America and & -0.017 & -0.020 \\
the Caribbean & $(-4.793)$ & $(-5.267)$ \\
& -0.012 & -0.014 \\
Log of initial income & $(-3.398)$ & $(-4.247)$ \\
& 0.012 & 0.012 \\
Log of schooling & $(2.878)$ & $(2.979)$ \\
& $-\mathbf{0 . 1 4 9}$ & $\mathbf{- 0 . 1 7 0}$ \\
Fractionalization & $\mathbf{( - 3 . 5 1 0 )}$ & $\mathbf{( - 4 . 1 3 5 )}$ \\
& & \\
Fractionalization * log of & $\mathbf{0 . 0 1 7}$ & $\mathbf{0 . 0 2 0}$ \\
initial income & $\mathbf{( 3 . 2 3 3 )}$ & $\mathbf{( 3 . 7 6 9 )}$ \\
& $\mathbf{0 . 0 0 1}$ & $\mathbf{0 . 0 0 1}$ \\
Democracy & $\mathbf{( 0 . 6 6 5 )}$ & $\mathbf{( 1 . 2 2 8 )}$ \\
& & \\
Fractionalization * & $\mathbf{- 0 . 0 0 2}$ & $\mathbf{- 0 . 0 0 3}$ \\
Democracy & $\mathbf{( - 1 . 0 6 7 )}$ & $\mathbf{( - 1 . 9 4 4 )}$ \\
& & \\
No of Observations & $82 ; 87 ; 93$ & $80 ; 85 ; 90$ \\
R-squared & $21 ; .33 ; .30$ & $.20 ; .39 ; .25$ \\
\hline
\end{tabular}

(t-statistics in parentheses)

Estimated using Seemingly Unrelated Regressions: a separate regression for each 10 year period. 
Table 5: Fractionalization and Population Growth in US Counties (dependent variable is growth in log of population 1970-2000)

\begin{tabular}{|c|c|c|c|c|}
\hline Variable & 1 & 2 & 3 & 4 \\
\hline Intercept & $\begin{array}{c}-0.088 \\
(-1.600)\end{array}$ & $\begin{array}{c}0.902 \\
-18.66\end{array}$ & $\begin{array}{c}-0.088 \\
(-1.600)\end{array}$ & $\begin{array}{c}0.906 \\
(18.690)\end{array}$ \\
\hline Log of population 1970 & $\begin{array}{c}0.034 \\
(5.610)\end{array}$ & $\begin{array}{c}-0.034 \\
(-6.860)\end{array}$ & $\begin{array}{c}0.033 \\
(5.170)\end{array}$ & $\begin{array}{c}-0.036 \\
(-6.910)\end{array}$ \\
\hline Income per capita $1970^{(a)}$ & $\begin{array}{c}.095 \\
(6.300)\end{array}$ & $\begin{array}{c}-0.071 \\
(-5.630)\end{array}$ & $\begin{array}{c}0.100 \\
(6.360)\end{array}$ & $\begin{array}{c}-0.068 \\
(-5.290)\end{array}$ \\
\hline Growth in log of population & & & & \\
\hline $1960-1970$ & & $\begin{array}{c}1.619 \\
(44.730)\end{array}$ & & $\begin{array}{c}1.620 \\
(44.740)\end{array}$ \\
\hline Northeast & $\begin{array}{c}-0.396 \\
(-12.480)\end{array}$ & $\begin{array}{c}-0.273 \\
(-10.960)\end{array}$ & $\begin{array}{c}-0.396 \\
(-12.410)\end{array}$ & $\begin{array}{c}-0.271 \\
(-10.800)\end{array}$ \\
\hline Central & $\begin{array}{c}-0.413 \\
(-19.740)\end{array}$ & $\begin{array}{c}-0.318 \\
(-19.330)\end{array}$ & $\begin{array}{c}-0.413 \\
(-19.610)\end{array}$ & $\begin{array}{c}-0.316 \\
(-19.080)\end{array}$ \\
\hline South & $\begin{array}{c}-0.115 \\
(-5.220)\end{array}$ & $\begin{array}{c}-0.137 \\
(-7.930)\end{array}$ & $\begin{array}{c}-0.116 \\
(-5.010)\end{array}$ & $\begin{array}{c}-0.143 \\
(-7.890)\end{array}$ \\
\hline Fractionalization 1960 & & & $\begin{array}{c}0.019 \\
(0.370)\end{array}$ & $\begin{array}{c}0.042 \\
(1.080)\end{array}$ \\
\hline No of Observations & 3133 & 3120 & 3120 & 3120 \\
\hline Adj. R-squared & .17 & .50 & .18 & .50 \\
\hline
\end{tabular}

(t-statistics in parentheses)

(a) Coefficient multiplied by $10^{3}$. 
Table 6: Fractionalization, Income and Population Growth in Counties (dependent variable is growth in log of population 1970-2000)

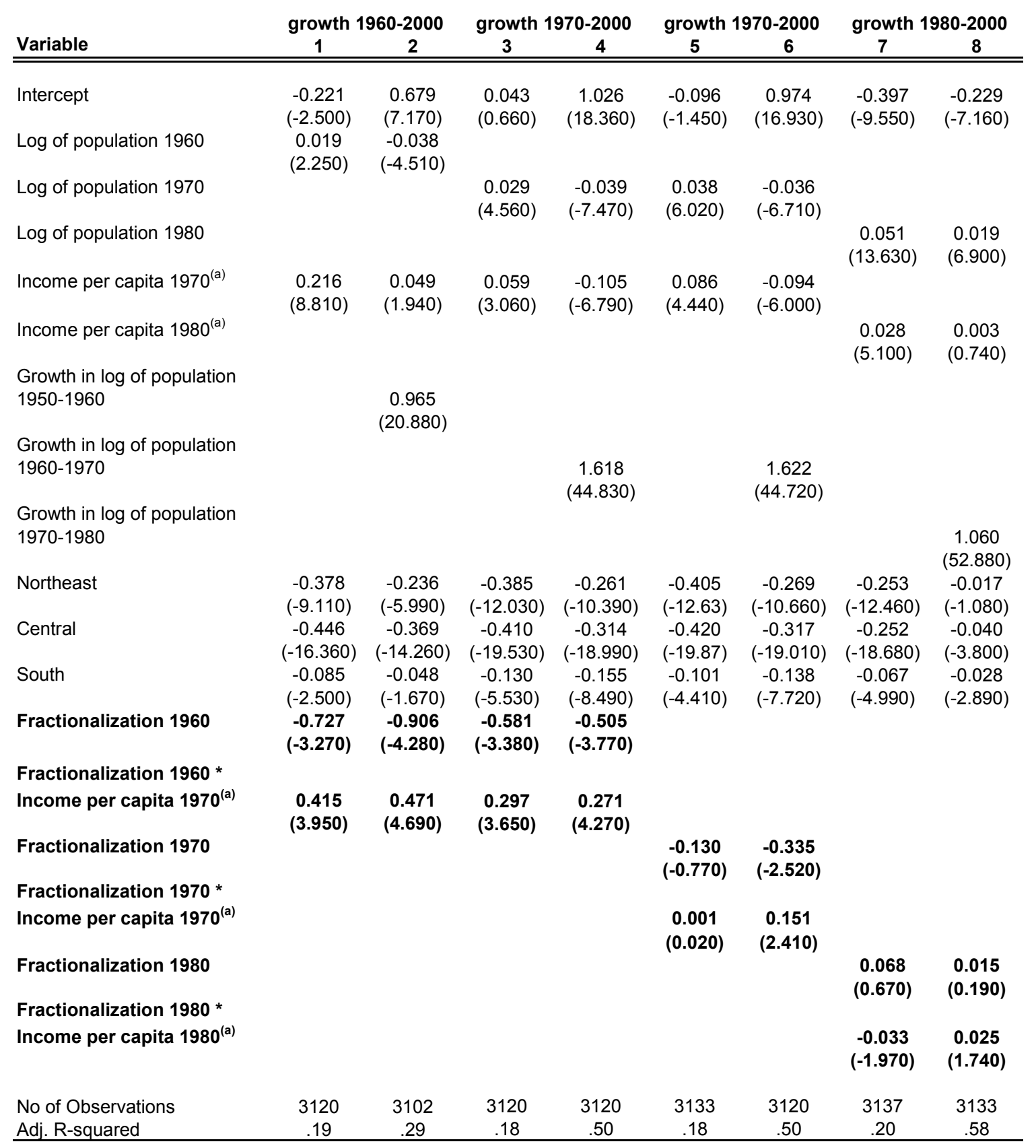

(t-statistics in parentheses)

(a) Coefficient multiplied by $10^{3}$. 